\title{
KENT MEYDANLARININ ERGONOMIK ÖLÇÜTLER AÇISINDAN DEĞERLENDİRİLMESİ: KADIKÖY RIHTIM MEYDANI ÖRNEĞİ
}

\author{
Simge KUTSAL GÖLLÜ1* ${ }^{*}$, Çiğdem CANBAY TÜRKYILMAZ²
}

${ }^{1}$ Yıldız Teknik Üniversitesi, Mimarlık Fakültesi, Mimari Tasarım Programı Doktora Öğrencisi, Barbaros Bulvarı, 34349, Yıldız İSTANBUL, ORCID No : https://orcid.org/0000-0002-5066-3959

${ }^{2}$ Yıldız Teknik Üniversitesi, Mimarlık Fakültesi, Mimarlık Bölümü, Barbaros Bulvarı 34349, Yıldız, İSTANBUL, ORCID No : http://orcid.org/0000-0002-8697-1259

\begin{tabular}{l}
\hline Anahtar Kelimeler \\
\hline Kent Ergonomisi, \\
Kamusal Alan, \\
Meydan Tasarımı, \\
Kadıköy Rıhtım Meydanı
\end{tabular}

$\ddot{0 ̈ z}$

Kentlerin ortak mekânı olan kamusal alanlar, insanların fiziksel, algısal ve sosyal ihtiyaçlarını karşıladıkları yerlerdir. Kamusal alanların kendilerine ait karakteristik özelliklerinin oluşmasında, insanların çevreleriyle kurdukları ilişsileri de etkilidir. Bu sayede kent kimliğinin ve kültürünün üretildiği alanlar haline gelirler. Kent meydanları kent kültürünün, sosyal canlılı̆̆ın ve farklı işlevlerin odağındaki kamusal alanların başında gelir. Bu anlamda, bütün yaş gruplarına, engelli, hasta, yaşll, çocuk gibi bedensel farklılıkları olan bireylerin kullanım ihtiyaçlarına eşit oranda cevap vermesi beklenir. Kullanım gereksinimlerini karşılarken, farklı kullanıcıların konforunun ve güvenliğinin de sağlanmasl; meydanlar ve kentsel donatıların ergonomik ölçütlere uygun olarak tasarlanmasıyla gerçekleşir. Bu doğrultuda çalışmada, İstanbul ilinde kullanıcı çeşitliliği, kullanım yoğunluğu ve karma fonksiyonlu yapısı nedeniyle Kadıöy Rıhtım Meydanı mekânsal, görsel, termal ve işitsel konfor açısından incelenmiştir. Meydandaki ergonomik koşullar gözlem ve yerinde ölçüm yoluyla belirlenmiştir. Meydanı deneyimleyen kentlilerle alanda görüşülerek uygulanan kullanıcı memnuniyeti anketiyle detaylı bir değerlendirme oluşturulmuştur. Bu anlamda alanın engelli kullanımına uygun olmadiğı gibi, işitsel ve termal konfor açısından da standartların oldukça gerisinde kaldığı ortaya çıkmıştır. Sonuçlar göstermektedir ki, kentsel donatıların tekil olarak ergonomik ölçütleri karşılaması meydanın kullanımında yeterli olmamakta, bütün olarak yeniden planlanması gerekmektedir. Kadıköy Rıhtım Meydanı gibi doğal çevre etkileşimi yoğun olan bir alanda temel ergonomik ve estetik ölçütlerden uzak meydan tasarımıyla karşslaşılmıştır. Elde edilen bulgular doğrultusunda öncelikle özel olarak Kadıköy Rıhtım Meydanı'nın ergonomik açıdan daha iyi bir seviyeye nasıl ulaşabileceği ve genel olarak kent meydanlarının tasarımında ergonominin nasıl katkı sağlayabileceği üzerine tartıșılmıștır.

\section{THE EVALUATION OF THE CITY SQUARES IN TERMS OF ERGONOMIC CRITERIA : A CASE STUDY OF KADIKÖY RIHTIM SQUARE}

\begin{tabular}{|c|c|}
\hline Keywords & Abstract \\
\hline $\begin{array}{l}\text { Urban Ergonomics, } \\
\text { Public Space, } \\
\text { Square Design, } \\
\text { Kadıköy Rıhtım Square }\end{array}$ & $\begin{array}{l}\text { Public spaces, which are the common spaces of cities, are the places where people meet } \\
\text { their physical, perceptual and social needs. As a result of people's relations with the } \\
\text { environment, the characteristic features of the public spaces are formed. They become } \\
\text { areas where urban identity and culture are produced through characteristic features. } \\
\text { The city squares are the main public areas of urban culture, social life and different } \\
\text { functions. In this sense, it is expected that all age groups will respond equally to the }\end{array}$ \\
\hline
\end{tabular}

\footnotetext{
*Sorumlu yazar; e-posta : simgekutsal@gmail.com
} 
usage needs of individuals with disabilities, patients, elderly and children. The comfort and safety of different users is ensured by designing the square and square urban building materials in accordance with the ergonomic criteria. In the study, Kadıköy Rihtım Square has been investigated in terms of spatial, visual, thermal and auditory comfort due to its diversity, usage density and mixed function structure. The ergonomic conditions in the square were determined by observation and in situ measurement. A detailed evaluation has been created with the user satisfaction survey applied to the square experienced. It was found that the area was not suitable for handicapped use, and it was behind the standards in terms of auditory and thermal comfort.

Araștırma Makalesi

Başvuru Tarihi

Kabul Tarihi
Research Article

Submission Date

Accepted Date
: 06.11.2018

: 15.12 .2018

\section{Giriș}

Kamusal alanlar, toplumun her kesiminden insanın karşılaştığı, iletişime ve etkileşime geçtiği alanlardır. Sokaklar, caddeler, bağlantı yolları, geçiş güzergahları, parklar ve meydanlar herkesin erişimine açık olan kamusal mekanlardır (Çelikyay ve Karayılmazlar, 2016).

Rapoport (1977) kamusal alanları, herkesin özgürce kullanabildiği, günlük aktivitelerini gerçekleştirdiği, insanların özgürce kendilerini ifade edebildiği ve diğer insanlarla iletişime geçebildiği mekanlar olarak tanımlar. Habermas (1995)'a göre, kamusal alanın en önemli niteliği tüm vatandaşlara açık olmasıdır. Şahin (2005) ise, kamusal alanları kent içinde gerekli ve vazgeçilmez mekanlar olarak gösterir. Kamusal alanlar herkes tarafindan kullanılır ve insanlar bu alanlarda yeni sosyal ilişkiler kurarlar.

Farklı tanımlardan anlaşılacağı gibi kamusal alanlar tüm kentlilerin kullanımına olanak tanıyan açık alanlar ile ilişkilendirilirler. Kentliler için kamusal alanlar arasındaki ayrımı mekanın kimliği belirler. $\mathrm{Bu}$ alanların gelişigüzel boşluklar veya geçişler olarak bırakılmaması; toplanma, buluşma ve gezme alanları yaratabilecek nitelikte, konforlu ve güvenli bir çevre yaratacak planlama kararlarıyla tasarlanması tercih edilen mekanların yaratılmasında önemlidir.

Kent meydanları, kamusal alanlar içinde kentlilerin kullanımı açısından sahip oldukları farklı işlevleriyle sosyal canlılığın odak noktasıdır. Kent merkezleri olarak, psikolojik ve duygusal yönden dinlenme, eğlenme ve fiziksel ihtiyaçlara cevap verici, ticari yönden aktif ve kültürel yönden katkı sağlayıcı nitelikler taşımalıdır. Bu özelliklerinin yanı sıra her türlü ulașım araçlarına da uygun ve ulașlabilir olmalıdır. Meydanlar, özel mekanların dişlayıcı karakterinin aksine, kentin bütününe yönelik kapsayıcı niteliğe sahiptir. Ne kadar farklı olursa olsun kentte var olan her şeyi ve herkesi içine alarak bütünleştirici ortamlar yaratır. $\mathrm{Bu}$ nedenle meydanların kullanıcı özelliklerinin önceden belirlenmesi mümkün değildir. Dolayısıyla kent meydanların tasarım ve düzenleme ölçütlerinde farklı kullanıcı grupları düşünülerek toplumun her bireyi göz önünde bulundurulmalıdır. Her yaş grubundan farklı kullanıcıların ihtiyaçlarına cevap veren tasarımlar ise ergonomik ölçütlerin doğru belirlenmesi ile gerçekleşebilir.

\section{Ergonomi Kavramı ve Kamusal Alanda Ergonomi Kriterleri}

Planlama ve tasarım sürecinde kamusal mekan organizasyonuna yön veren üç temel bileşen bulunmaktadır. Bunlar; erișebilirlik, ergonomik ölçütler ve estetik değerlerdir (Çelikyay ve Karayılmazlar, 2016). Erişebilirlik, özünde herkes için eşit kullanım hakkıdır. Doğrudan ergonomiyle ilişkilidir.

Genel olarak ergonomi, insan, donanım, çalışma alanı ve çevresi arasındaki ilişkileri inceleyen ve bunlardan doğan problemler setine anatomi, fizyoloji ve psikoloji bilimlerinin temel bulgularını uygulamaya çalışan bilim dalıdır (Ünügür, 1988; Çekmecelioğlu vd., 2017). Ergonominin temelinde "insan konforu" bulunur. İnsanlar arasındaki ve insanlarla nesneler arasındaki döngüsel ilișkileri inceler. Bu anlamda; anatomi, fizyoloji, psikoloji, antropoloji, nöroloji ve davranış bilimleri gibi insana dair bilimlerle ilişki içerisindedir. İş yöntemlerinin, araç gereçlerin ve geniş anlamda çevrenin, insan yapısına, işlev ve yetilerine göre tasarlanmasına yardımcı olur. Kısacası insanı değil, insan için çevreyi değiștirir. Çevre kurucu öğelerin insana en uygun olabilecek şekilde tasarlanmasının koşullarını önerir (Doğan ve Altan, 2007).

Herhangi bir çevrenin ya da nesnenin tasarımında ilk ölçüt daima insandır (Doğan ve Altan, 2007). Bu nedenle insanın boyutlarının, hareket kabiliyetinin ve sınırlarının bilinmesi birincil şarttır. Bunun için antropometrinin verilerinden yararlanılır. Antropometri özellikle karşılaştırma amaçlı olmak 
üzere, insan bedeni ölçülerinin araştırılmasıdır (Baytin, 1988).

Antropometri, insan vücudunun biçim, boyut, fiziksel yapısına bağlı hareketlerini ve bunların sınırlarıyla ölçülebilir kavramlara ulașmaktadır (Doğan ve Altan, 2007). Farklı bölgelere ait insan gruplarının antropometrik ölçülerinde değişiklik görülür. Ürün ve sağlıklı yaşam çevrelerinin tasarımında kullanılmak üzere, o topluma ait antropometrik normların oluşturulması gerekir.

Ergonomi, genel olarak, insan verimliliğini ve konforunu sağlayacak şekilde yapılı çevrenin tasarlanması ve düzenlenmesi ile ilgilenirken, tasarlanan çevrenin kullanıcılarının hoşuna gidecek, sağlık ve güvenliğini sağlayacak ve yaşam kalitesini arttıracak ortamlara dönüştürmeyi de amaçlamaktadır. Ancak kamusal alanlar gibi farklı kullanıcı gruplarına yönelik tasarımlar söz konusu olduğunda ergonomik ölçütlerin; toplumun fiziksel özellikleri, toplumsal ve kültürel nitelikleri, estetik ve sanat anlayışları gibi genel dinamiklerine uygun olması gerekir (Cekmecelioğlu vd, 2017). Kamusal alanların, tüm yaş gruplarına, engelli, hasta, yaşlı, çocuk gibi bedensel farklılıkları olan kişilerin kullanım gereksinmelerine eşit oranda cevap vermesi beklenmektedir.

Kamusal alanlar ve meydanlar bireylerin sosyal, kültürel, fiziksel ve psikolojik ihtiyaçlarına bağlı olarak özel donatıların bulunduğu yerlerdir (Bayramoğlu ve Özdemir, 2012). Kamusal mekândaki donatı elemanları, kentsel yaşamı daha zevkli ve anlaml kılmaya, kentsel konfor ve kentsel estetik yaratmaya olanak verirler (Yücel, 2006). Kentsel donatılarla birlikte bir bütün oluşturan meydanlar yaratmak için, donatı elemanlarının tasarımında kullanıcıların ergonomik özelliklerinin yanı sıra, tasarımları ve konumlarında çevre karakterini yansıtan çözümlere de yer verilmelidir. Bu sayede kullanıcıların meydanı "yer"in bir parçası olarak görmeleri, aidiyet hissetmeleri ve çevresel ilişki kurmaları kolaylaşacaktır. Kent dokusunda donatı elemanlarının hatalı seçimi ve kullanımı kargaşaya neden olmakla birlikte görsel kirlilik de yaratmaktadır. $\mathrm{Bu}$ nedenle objelerin seçiminde, tasarımında ve kullanımında kent kalitesinin yükseltilmesi ve modern kent görünümü yaratılması ana hedef olmalıdır (Şişman ve Yetim, 2004).

"Yaşanılan çevrede; yol, cadde, sokak ve meydanlar ile rekreasyon amaçlı olarak kullanılan özel ya da genel kullanım alanlarında bulunan, konfor sağlamasına ek olarak oturma, korunma, barınma, kuşatma, danışma, ulaşım, betimleme, aydınlatma, iletişim, oyun ve spor gibi temel faaliyet ve fonksiyonları destekleyip güçlendiren, toplumsal yaşamı kolaylaştırarak kullanıcıların beğenilerini kazanan peyzaj elemanları kentsel donatı olarak tanımlanmaktadır" (Başal vd., 1997; Şişman ve Yetim, 2004).

Açık kamusal alanlarda yer alacak kamusal mekan donatılarının tasarımı, seçimi ve alanda konumlandırılmasında hem ergonomik hem de estetik açıdan göz önünde bulundurulması gereken bazı prensipler söz konusudur. Bunlar;

Aydınlatma Elemanları: Diş mekan aydınlatmasının amacı sanatsal, oyun, çalışma ve koruma içindir (Şişman ve Yetim, 2004). Kentsel mekanın gece kullanımının artması ve güvenli ortamın yaratılması doğru aydınlatma elemanlarının seçimiyle mümkün olur. Aydınlatma elemanlarının yerleşiminde karanlık nokta ve alanların oluşmasının önüne geçilmelidir. Yol, meydan, park, bahçe, gezi alanları, yaya yolları gibi yerlerin aydınlatılmasında kullanılan aydınlatma elemanlarının her birinin aydınlatma özellikleri kadar boyut, biçim, gereç, taşınma sistemleri, sayıları ile kent görüntüsü üzerinde gündüz ve gece etkileri de önemlidir. Bu tür bir etkide çevre ile uyum değerlendirilmesi gereken önemli bir konudur (Şerefhanoğlu, 1991).

Sınırlayıcılar: İnsan ve araç trafiğinin kesiştiği noktalarda, esas amacı araç trafiğinin kontrol altında tutulması olan, görsel açıdan bireyleri kısıtlamayan düzenleme elemanlarıdır. Sınırlayıcılar estetik açıdan kullanılacağı ortamın mimari anlayıșı ile uyumlu olmalıdır.

Estetik ve fonksiyon prensiplerinin yanı sira psikolojik etkilerinin de göz önünde bulundurulması gerekir. Mahremiyet ve kötü görünüm engellenmek isteniyor ise insan boyundan yüksek $(180-250 \mathrm{~cm})$ ve masif; insanların girmesi engellenmek isteniyorsa üzerinden aşllamayacak kadar yüksek (80-140cm) ve arasından girilemeyecek kadar dar; park ve çevredeki güzel görünümlere açı olması isteniyorsa, sınırlayıcı eleman kısmen açık ve alçak (20-60cm), tercihen hiç olmamalıdır (Yücel, 2006).

Oturma Elemanları: Oturma elemanları meydan gibi kamusal alanları yaşayan mekanlara dönüştürürler. İnsanlar; dinlenmek, oturmak, sohbet etmek, izlemek veya gözlem yapmak amacıyla oturma elemanlarını kullanırlar. Oturma elemanlarının boyutları, malzemesi ve tasarımı, kullanıcıların fiziksel konforunu doğrudan etkilemektedir (Yücel, 2006).

Oturma birimlerinin kamusal alanda doğru konumlandırılması ergonomik, erişebilirlik ve estetik açıdan olumlu algı yaratacaktır. Banklar yol akışını kesmemesi için yoldan $60 \mathrm{~cm}$. içeriye 
yerleștirilmeli, oturma yerlerinin hiç olmazsa bir yanında, tekerlekli sandalye kullanıcılarının yanaşabilmeleri için en az $90 \mathrm{~cm}$. genişliğinde düz alan bırakılmalıdır (Yücel, 2006).

Çöp Kutuları: Dış mekanda kirlenmeyi önlemek üzere kullanılan, değişik malzeme ve biçimlerde yapılmış donatı elemanlarıdır. Daha çok işlevsel amaçlar için kullanılmakla birlikte (Şişman ve Yetim, 2004), tekil olarak ya da diğer donatılar ile birlikte düşünülerek tasarlanabilirler. Bazı durumlarda diğer donatı elemanları ile birlikte de tasarlanabilirler.

Çöp kutularının en çok gereksinim duyulabilecek noktalara yerleştirilmesi gerekir. Kolayca görünmeli ve yaya akışını, engelli geçişini engellemeyecek biçimde konumlandırılmalıdırlar. Çöp kutularının sayısı alanı kullanan kişi sayısı ile bağlantılıdır. Normal olarak 30 m. ara ile yerleştirilmeleri gerekir. Ancak yoğun kullanılan kamusal alanlarda bu mesafe daha da azalabilir (Yücel, 2006). Meydan gibi yoğun kullanım alanlarında çöp kutularının kapaklı olması hem yağmurlu havalarda çöpün dağılmamasına hem de kötü görüntünün ve kokunun oluşmasını engeller.

Bitki Kasaları: Bitkiler için yaşama ortamı sağlayan, estetik ve işlevsel amaçlar için kullanılan donatı elemanlarıdır (Şişman ve Yetim, 2004). Bitki kasaları bulundukları yere renk ve canlılık katar. Alandaki konumları yaya geçişine ve engelli kullanımına engel teşkil etmemelidir. Gerekli durumlarda yol kenarlarında sınırlayıcı olarak kullanılabilirler.

Yön ve İşaret Levhaları: Gidilecek noktayı belirlemede önemli bir işlevi olan yön ve işaret levhaları özellikle kalabalık ve çok işlevli kamusal alanlarda insanların kolayca görebilecekleri şekilde konumlandırılmalıdır. İşaretleme olumlu ve bilgi verici olmalı; insanlara tek başlarına hareket etme rahatlığı vermelidir (Yücel, 2006). İşaret levhalarının kent içindeki yerleşimlerinde yükseklik ve kullanım noktalarına dikkat edilmelidir. Engelli bireylerin de levhalardan yararlanacağı unutulmamalı bütün insanlar için ulaşılabilir olmalıdır.

Resim, Heykel ve Plastik Öğeler: Kamusal alanlarda görsel algı yaratan ve estetik değer taşıyan sanat objeleridir. $\mathrm{Bu}$ anlamda heykeller kompozisyonu tamamlayan elemanlardır. Bazı durumlarda mekanda simgesel anlamlar da taşırlar (Yücel, 2006). Heykellerin insanları bir araya getirip kaynaştırma ve kültür alışverişini sağlama gibi işlevleri bulunur. Ayrıca heykeller özgün, belirleyici özellikleri ile alanda gerçekleşen etkinlikler ve elde edilen diğer deneyimler ya da algılarla birlikte mekana ve kente ilişkin bireysel ve/veya toplumsal imgeler oluştururlar (Öztürk Kurtaslan, 2005).
Plastik öğenin rengi, malzemesi ve dokusu ile arka planda kalan görüntünün kontrast yaratması, detayların algılanmasında ve görsel konfor ölçütlerinde temel tasarım ilkesini oluşturur.

Su Öğeleri: Su öğeleri fiziksel ve psikolojik açıdan en önemli çevresel elemanlardandır. Kentsel mekana cazibe ve estetik katmanın yanı sıra rekreasyonel aktiviteler için de bir araçtır (Gedik, 2003; Bayramoğlu ve Özdemir, 2012; Çelikyay ve Karayılmazlar, 2016). Su öğeleri kamusal alandaki odak noktasını, toplanma ve buluşma noktasını oluşturur.

Üst Örtü Öğeleri: Üst örtü öğelerinin, gölge sağlama, yağmurdan koruma, dinlenme, pasif rekreasyon ve mekana üçüncü boyut sağlama gibi fonksiyonları vardır (Yücel, 2006). Kamusal alanlarda, özellikle meydan gibi büyük açıklıkların olduğu alanlarda, gölgelik elemanlar termal konforu sağlamada önemlidir. Oturma birimleriyle bütün olarak düşünülmesi gereken üst örtüler, hava akışını engellemeyen ve çevreyle uyumlu doğal malzemelerden seçilmelidir.

Donatı elemanları, insanın kent dokusu içindeki bireysel ve toplumsal yaşamını kolaylaştıran, bireyler arası iletişimi sağlayan, mekana kullanım ve estetik açıdan belirli bir anlam kazandıran, değişik nitelik ve niceliklerde olan, mekanı tanımlayan ve tamamlayan objelerdir. Sadece işlevsel değil kent peyzajını (Kuşkun, 2002; Bayramoğlu ve Özdemir, 2012) ve kent yaşamını canlandırıcı etkileri açısından büyük önem taşır. Bu nedenle donatı elemanlarını bir bütün olarak değerlendirmek ve meydanlarda bütünün parçaları olarak konumlandırmak gerekir.

\section{Yöntem}

Kadıköy Rıhtım Meydanı, Marmara Denizi ile olan ilișkisi ve Anadolu yakasındaki konumu, ulașım çeşitliliği ve her kullanıcı profiline hitap edebilecek çevresel fonksiyonlarıyla kamusal kullanım açısından potansiyeli yüksek meydanlardan bir tanesidir. $\mathrm{Bu}$ nedenle çalışmada örneklem alanı olarak seçilmiştir.

Çalışmada, örneklem alanı içerisindeki kentsel donatıların kullanıcı bağlamında ergonomik özellikleri yerinde tespit, gözlem, kullanıcı anketi ve ikili görüşme gibi farklı metotların kullanımı ile incelenmiștir. I. Așamada, sınırlandırılan örneklem alanında bulunan mevcut donatı elemanları ve konumları fotoğraflanmış, olumlu ve olumsuz yönleri yerinde tespit edilmiştir. Kentsel donatılar, fonksiyonları, malzeme özellikleri ve boyutlarına 
göre sınıflandırılarak, konumları harita üzerinde işaretlenmiştir. II. aşamada, konuyla ilgili önceki çalışmalardan yararlanılarak, meydana dair veriler sınıflandırılmıştır. Örneklem alanındaki su öğesi, üst örtü, aydınlatma, zemin kaplaması, oturma ve atık birimleri, bitki kasaları, sınırlayıcılar, yön ve ișaret levhaları, otobüs durakları, satış birimleri, telefon kulübeleri ve plastik öğeler kullanılan malzeme, kullanıldığı yer, kullanım amacı ve fonksiyonuna göre yapılan analiz ve gözlemler sonucunda erişebilirlik, ergonomik ölçütler ve estetik değerler açısından değerlendirilmiştir. III. aşamada, demografik özellikler ve ergonomik ölçütleri değerlendirmeye yönelik iki kısımdan ve 16 sorudan oluşan anket formu alanda farklı gün ve saatlerde toplam 60 kişiyle gerçekleştirilmiştir. Bulguların ve anket sonuçlarının karşılaştırmalı analizinden sonra alanın mevcut durumunun iyileștirilmesine yönelik öneriler çalışmanın IV. ve son bölümünü oluşturmaktadır.

Kadıköy Rıhtım Meydanı özelinde yürütülen bu çalışmanın amacı, mevcut kentsel donatıların ergonomik açıdan verimli olup olmadığı, kullanıcı uyumu, kullanışlılığı ve memnuniyetinin saptanarak, öncelikle özel olarak örneklem alanının ergonomik açıdan daha iyi bir seviyeye nasıl ulaşabileceği ve genel olarak kent meydanlarının tasarımında ergonominin nasıl katkı sağlayabileceği üzerine tartışma ortamının yaratılmasıdır.

\section{1. Çalışma Alanı}

İstanbul'un Anadolu yakasında yer alan, Kadıköy İskele Meydanı olarak da bilinen Kadıköy Rıhtım Meydanı, esas olarak Haydarpaşa Tren Garı ile İnciburnu Feneri arasında "C" şeklinde uzanan sahil şeridinden oluşur. Batısı Marmara Denizi'yle, doğusu Haydarpaşa-Moda hattını oluşturan Rıhtım Caddesi ile sinırlıdır. Kadıköy'ün ana aksılarından biri olan Söğütlüçeşme Caddesi, Rıhtım Meydanı'yla orta noktasından kesişmektedir (Şekil 1).

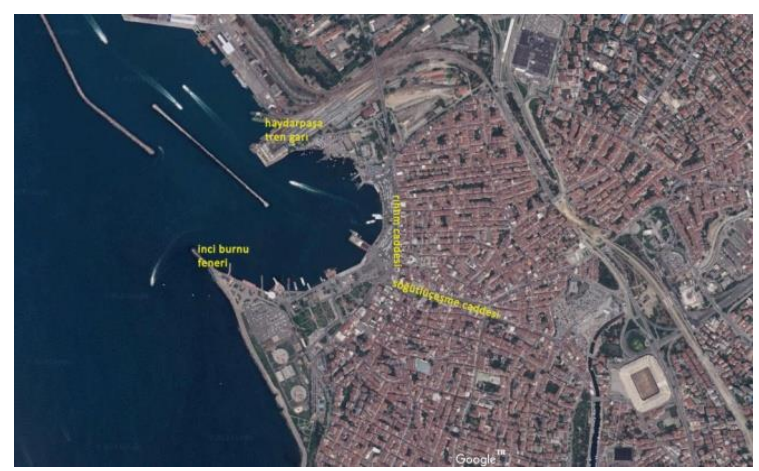

Şekil 1. Kadıköy Rıhtım Meydanı Çevresi (google earth üzerinden hazırlanmıştır)

Haydarpaşa Tren Garı ile Eminönü-Karaköy İskelesi arasında, İETT Otobüsleri ve minibüs hatlarına ait durak yerlerinin olması nedeniyle meydanın bu kısmı niteliğini kaybetmiş durumdadır. Konu edilen alanın kaotik kullanımı kentlinin denizle olan ilişkisini kesintiye uğratmaktadır. İnciburnu Feneri yönünde ise denizle olan ilişki İSPARK'a ait otopark alanı tarafından engellenmiştir. Bu nedenle, meydan özelliği gösteren Eminönü-Karaköy İskelesi ile İSPARK arasında kalan bölüm örneklem alanı olarak belirlenmiştir (Şekil 2).

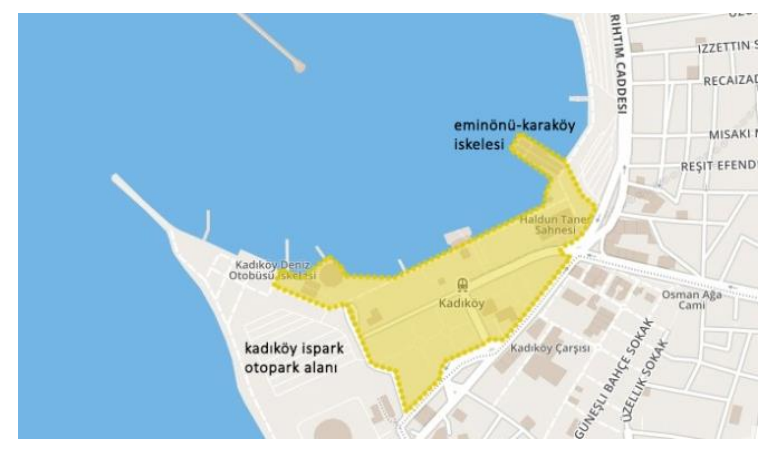

Şekil 2. Kadıköy Rıhtım Meydanı Çevresi (labs.strava üzerinden hazırlanmıştır)

Örneklem alanı içinde Kadıköy'ün en güzel yapılarından Haldun Taner Sahnesi yer alır. 1920'li yıllarda meyve ve sebzelerin satış alanı olarak inşa edilen yapı, 1980'li yıllarda hal işlevinin kaldırılmasıyla İstanbul Üniversitesi'ne devredilmiştir. Günümüzde binanın zemin katı İstanbul Şehir Tiyatroları Kadıköy Haldun Taner Sahnesi, diğer katları İstanbul Üniversitesi Devlet Konservatuarı olarak kullanılmaktadır.

Alan sınırlarının içindeki bir diğer tarihi yapı 19121914 yıllarında denizin doldurulmasıyla elde edilen meydana inşa edilen Şehremaneti Binası'dır (Atılgan, 2017). Beşiktaş-Kabataş Vapur İskelesi'nin tam karşısında konumlanan yapı Ermeni Mimar Yervant Terziyan tarafından tasarlanmıştır.

1995'te restorasyon geçirerek Kadıköy Kaymakamlığı, Belediye Başkanlığı ve Belediye Meclis toplantılarının yapıldığı bir bina olmuștur. Günümüzde Kadıköy Belediyesi'ne bağlı Tarih Edebiyat ve Sanat Kütüphanesi olarak kullanılmaktadır (Şekil 3). 


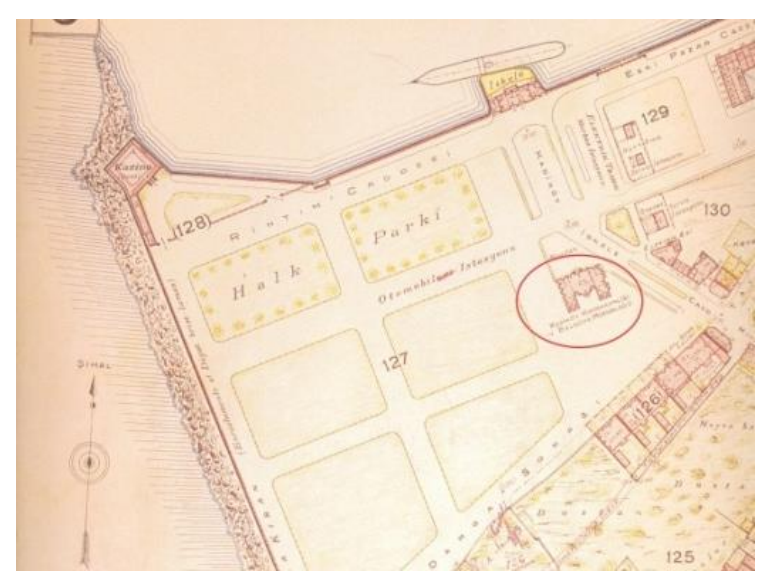

Şekil 3. Denizden Doldurulan Meydanda Şehremaneti Binası, 1938 (Atılgan, 2017)

1930'lu yıllardan itibaren Kadıköy Rıhtım Meydanı'na İstanbul kentsel çalışmaları içinde projeler oluşturulmuş ancak hiçbiri uygulamaya konulmamıştır. 1950'li yıllarda İstanbul'un bütününde olduğu gibi Kadıköy'ün genel dokusunu değiştirecek hareketler başlamıştır. Bunun sonucunda çeşitli bölgelere Kadıköy'den yollar açılmış, çalışmalar 1980'lere kadar sürmüştür. Kadıköy Rıhtım Meydanı yapılan çalışmalardan etkilenmiş, meydan şekli ve boyutu değişiklikler göstermiştir. 1984-1993 yıllarında Rıhtım Meydanı ile Mühürdar arasında deniz doldurularak meydan genişletilmiş (İnceoğlu, 2007).

Son yıllarda meydanın yayalaștırılarak yeniden düzenlenmesi, meydanla ilişkili kent camisi ve yat limanı (Bayhan, 2011 ve 2016; Gürsel, 2012; Yılmaz Gürkan, 2015; Karakoç, 2017) yapılması gibi büyük ölçekli kentsel kararlar Büyükşehir Belediyesi'nin gündemindedir. İBB'nin 2014 yılında duyurduğu Kadıköy Meydan Projesi, Haydarpaşa'dan İnciburnu Feneri'ne kadar olan sahil bandının yayalaştırılmasını kapsamaktadır (Bayhan, 2016) (Şekil 4). Bu amaçla 2016 yılında çalışmalara başlanmış, deniz üzerinin doldurularak alanın genişletilmesi tamamlanmıştır. Günümüzde bu çalışmaların devamının geleceğine dair izlere rastlanmamaktadır. İBB'den veya Kadıköy Belediyesi'nden proje hakkında bilgilendirici bir açıklama yapılmamıştır.

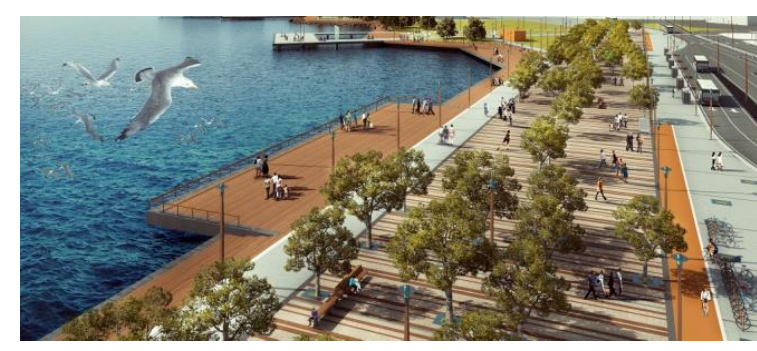

Şekil 4. Kadıköy Meydanı Yenileme Projesi (Bayhan, 2016)

Kadıköy Rıhtım Meydanı, İstanbul şehir içi ulaşımında önemli bir yere sahiptir. Buradan Şehir Hatları Vapur Seferleri, İstanbul Deniz Otobüsleri ve özel bir ișletme olan Turyol deniz motorları ile Eminönü, Karaköy, Beşiktaş, Kabataş, Bostancl, Adalar, Yenikapı, Avcılar ve Bursa'ya deniz ulaşımı, birçok otobüs, dolmuş ve minibüs güzergahı ile Anadolu yakasındaki her ilçe ve semte karayolu ulaşımı sağlanmaktadır. Kadıköy-Kartal Metro hattının son durağı doğrudan meydan sınırları içinde yer almaktadır. Çeşitli ulaşım ağlarının kesişim noktası olması meydanı günü her saati kalabalık, insan hareketinin ve çeşitliliğinin yoğun olduğu bir kamusal alan haline getirmektedir.

\section{Sonuçlar}

Kadıköy Rıhtım Meydanı, denizle kurduğu ilişki nedeniyle alışılmışın dışında bir meydan yaratır. Meydan üç taraftan yapılar ile sarılıdır. Binalar ile alan arasında yolların olması ve ölçü olarak büyük bir alanı kaplaması nedeniyle tam bir kapalılık hissi oluşturmamaktadır. Kadıköy Rıhtım Meydanı'nın derinliği ortalama 245 metre, ortalama genişliği 145 metredir. Bu boyutlar kullanıcıların geniş ve ferah bir mekan hissi ile çevrelenmesine olanak tanır. Ancak bu genișlik ve boşluk alanın kullanımında olumsuzluklar da yaratmaktadır. Meydanın batı ve güneybatı kısımlarında boş ve tenha alanlar bulunurken, toplu taşıma ile ilişkilendirilmiş kuzey alanında insan sirkülasyonu oldukça yoğundur.

Meydan bütünlüğünün araç yolları ile defalarca kesintiye uğraması alanın parçalara ayrılmasına neden olmakta, bütün olarak algılanmasını ve kullanılmasını engellemektedir (Şekil 5). Bu kesintinin bir sonucu olarak da meydan, ișlevini kaybederek geçiş güzergahı, sahil yolu ve yürüyüp gidilen bir rota haline gelmektedir. 


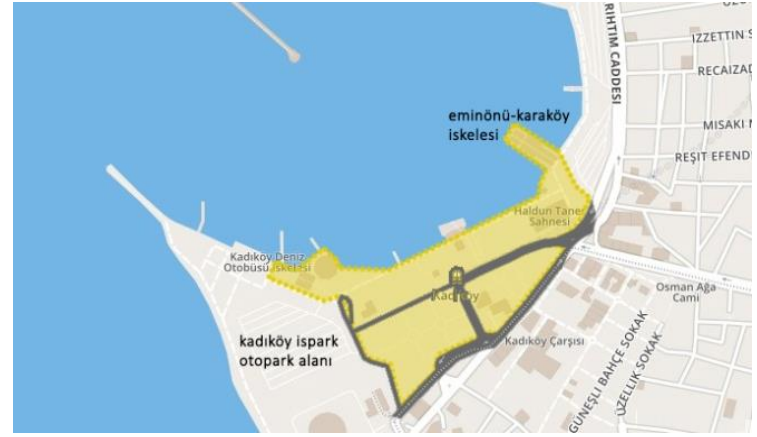

Şekil 5. Meydanı Bölen Yol Güzergahları (labs.strava üzerinden hazırlanmıștır)

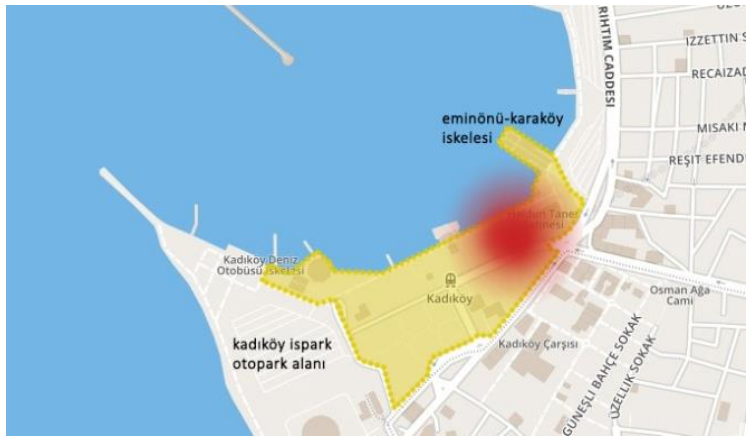

Şekil 6. İnsan Yoğunluğunun Toplandığı Alanlar (labs.strava üzerinden hazırlanmıștır)
Meydana toplu taşıma araçlarıyla erişim sağlanmaktadır. Özel araç kullanımına yönelik yakın çevrede otopark alanları bulunmaktadır. Ancak otopark alanlarının konumu tartışılması gereken bir konudur. Çünkü Kadıköy'ün en büyük otoparklarından biri olan İSPARK otopark alanı meydanın güneybatısında bulunmakta, kentlinin denize erişimini ve meydanın bütüncül algısını engellemektedir. Alan aynı zamanda Kadıköy-Moda arasındaki yaya ulaşımını da kesintiye uğratmaktadır. Ayrıca alanın yakın çevresinde günün her saati trafik olmakta ve meydandaki işitsel konfor koşulları olumsuz yönde etkilenmektedir. Üstelik araç park eden insanların büyük bir çoğunluğu doğrudan meydanı kullanmaya gelmemektedir.

Kent meydanları barındırdıkları öğeler, işlevler ve aktiviteler bakımından farklı yoğunluklarda kullanılmaktadırlar. Özellikle yaya hareketlerinden gelen yoğunluğun meydanın hangi bölgelerinde toplandığının analizinin yapılması, tasarımında, donatı yerleşiminde, aktivitelerin düzenlenmesinde veya yeşil alan yaratmada uygun alanların belirlenmesi için yardımcı olmaktadır (Çekmecelioğlu vd., 2017).

Meydanda yaya hareketine yönelik yürütülen farklı gün ve zamanlardaki gözlemler sonucunda alanın, ulaşım araçlarına erişim sağlamada ve kentlinin buluşma noktası olarak kullanıldığı anlaşılmaktadır. $\mathrm{Bu}$ nedenle insan yoğunluğu, toplu taşıma araçlarının kesiştiği vapur iskeleleri arasında, otobüs durakları, Haldun Taner Sahnesi ve metro çıkışında yoğunlaşmaktadır (Şekil 6). Güneybatıya gidildikçe yoğunluğun azaldığı, özellikle akşam saatlerinde yaya ulaşımı açısından tenhalaştı̆ı̆ görülmektedir.

\subsection{Kadıköy Rıhtım Meydanı'nın Ergonomik Açıdan Analizi}

Kadıköy Rıhtım Meydanı mekansal konfor, görsel konfor, işitsel konfor ve termal konfor açısından; kentsel mekanı çekici kılan donatılar ise antropometrik ölçüler ve estetik değerler bağlamında incelenmiştir. Meydandaki kentsel donatılar aydınlatma elemanları, sınırlandırıcılar, oturma birimleri, çöp kutuları, bitki kasaları, telefon kulübeleri, otobüs durakları, plastik öğeler, büfeler, satış birimleri, yön ve işaret levhaları olarak belirlenmiştir. Meydanın görsel açıdan bütünlüğünü oluşturan yeşil alanlar ve zemin döşeme malzemeleri; erişebilirlik ölçütleri açısından önem arz eden merdiven ve rampalar değerlendirilmiștir.

Kamusal açık alanlarda bulunabilecek su öğesi Kadıköy Rıhtım Meydanı içinde yapılı çevre elemanı olarak bulunmamaktadır. Doğal sınır olan Marmara Denizi'nin meydanla kurduğu ilişki su öğesi etkileşiminin karşılanmasında yeterlidir (Şekil 7).
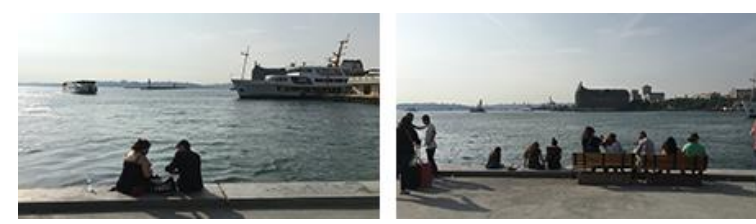

Şekil 7. Meydan - Su İlişkisi (Kutsal Göllü미, 2018)

Meydan-su ilişkisinin görsel etki ile sınırlı kalması ve kentlinin doğrudan su ile etkileşime geçebildiği düzenlemelerin geliştirilmemesi nedeniyle meydanın sahip olduğu potansiyel meydan kullanıcısına aktarılamamıştır.. Özellikle kıyı boyunca görülen vapur iskelelerinin birbiriyle olan uyumsuzluğu görsel algı açısından olumsuz etki yapmaktadır (Şekil 8). 

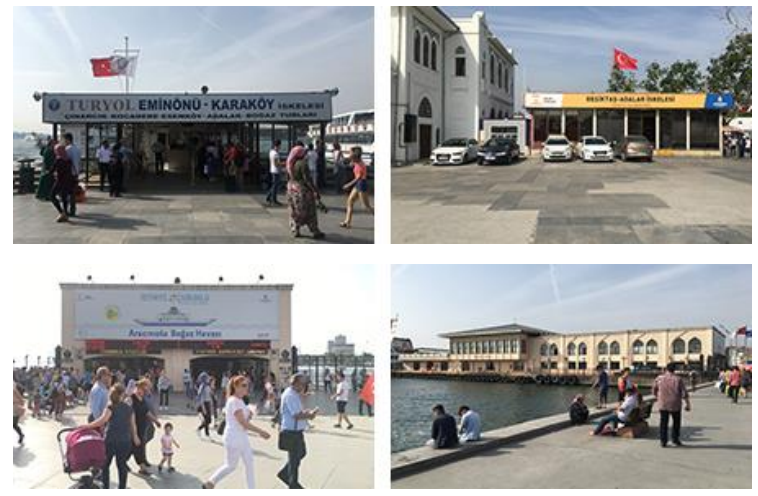

Şekil 8. Meydandaki İskele Binaları (Kutsal Göllü, 2018)

Kamusal alanlarda bulunması gereken bir diğer kentsel donatı elemanı olan üst örtü öğesi, örneklem alanı içinde bulunmamaktadır. Ölçek olarak büyük kentsel alanlardan olan Rıhtım Meydanı'nda gölgelendirme elemanının olmaması termal konfor açısından olumsuz sonuçlar yaratmaktadır. Özellikle sıcak öğlen saatlerinde insanların ağaç, heykel, bina vb. gölge alanlarda yoğunlaştığı ve buralardaki oturma birimlerini kapasitelerinin üzerinde kullanıldıkları tespit edilmiştir (Şekil 9).
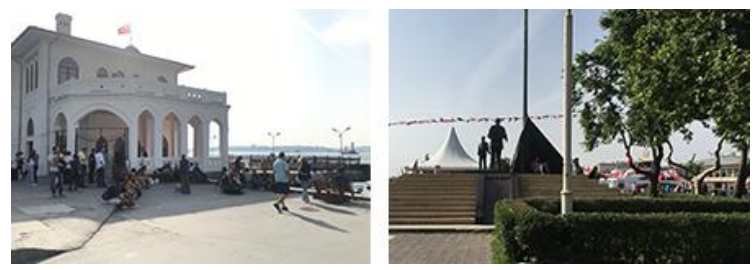

Şekil 9. Gölge Alanlar ve Oturma Koşulları (Kutsal Göllü, 2018)

Örneklem alanında bulunan tek üst örtü özel bir işletmeye ait olmakla birlikte hem ergonomik ölçütler hem de estetik açıdan olumsuz görüntü yaratmaktadır (Şekil 10). Yürütülen anket çalışmasında ankete katılanların \%86,7 gibi bir oranı gölgelendirme elemanlarının olmayışını "olumsuz" olarak değerlendirmiştir.
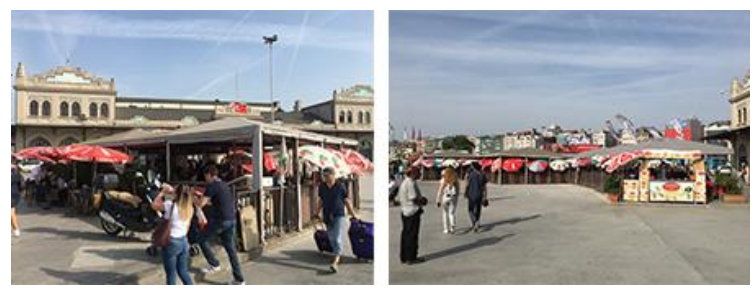

Şekil 10. Meydandaki Üst Örtü (Kutsal Göllü, 2018)
Meydandaki aydınlatma elemanları genel olarak yol ve sahil hattına paralel doğrultuda yerleştirilmişlerdir. Kentin farklı bölgelerinde kullanılan aydınlatma öğeleri, burada da aynen kullanılmıştır. Alanda saptanan aydınlatma elemanları çok çeşitli olmakla birlikte ölçü, biçim ve malzeme açısından birbirleriyle de bütünlük oluşturmamaktadır. Yeşil yoğunluğu fazla olan alanlarda, aydınlatmanın yetersiz kaldığ l ve karanlık noktalar oluştuğu gözlenmiştir. Bu durum görsel konforu olumsuz yönde etkilediği gibi gece kullanımında güvenlik açısından tehlikeli yerler oluşturmaktadır (Şekil 11). Aydınlatma öğeleri yalnızca fonksiyonel olarak değil, kamusal alanlarda tasarım objesi olarak da ele alınmalıdır.

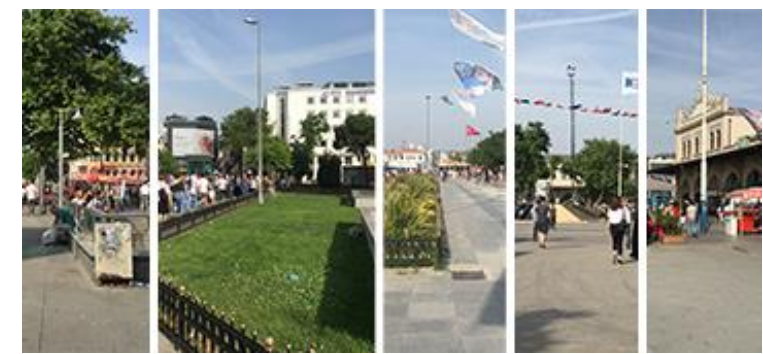

Şekil 11. Aydınlatma Elemanları (Kutsal Göllü, 2018)

Anket çalışmasında aydınlatma elemanlarının özgün ve estetik olmadığ 1 vurgulanarak, \%56,7 oranında ne iyi ne kötü, \%23,3 oranında kötü olarak nitelendirilmişlerdir. Yapılan görüşmeler sırasında kentlinin donatı olarak her yerde görmeye alıştığı bir öğeye değerlendirme yapmayı "gereksiz" bulduğu gözlenmiştir.

Meydandaki gözlemler sırasında alan çevresinde iki nedenden dolayı sinırlayıcılara rastlanmıştır. Bunlardan ilki araç trafiği ile meydandaki yaya trafiğini birbirinden ayırmak, ikincisi ise, çimlik yeşil alanlara yaya girişini engellemektir. Her iki durumda da sinırlayıcı elemanlar ergonomik ölçütler doğrultusunda, ihtiyaca göre alçak ve orta yükseklikte kullanılmış; ancak malzeme, model ve kullanım açısından uyumlu bir tasarım yaratılmamıştır. Araç trafiği ile yaya trafiğini birbirinden ayıran sınırlayıcılar aynı yol üzerinde üc farklı model kullanılarak gerçekleştirilmiștir (Şekil 12). Metal çubuklar şeklinde tasarlanan bu öğeler bazı yerlerde beton bitki kasaları ile desteklenmiştir. 

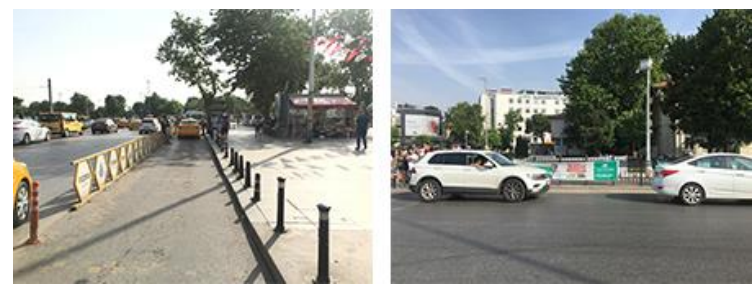

Şekil 12. Yol Çevresinde Bulunan Farklı Yükseklik ve Tasarımda Sınırlayıcı Elemanlar (Kutsal Göllü, 2018)

Mevcut meydan düzeninde sinırlayıcı kullanılmasına gerek olmayan alanlar arasinda da sinırlayıciların kullanıldığı gözlenmiștir (Şekil 13). Bu durum kentli için yaya ulaşımında engel teşkil etmekte ve tekerlekli sandalye kullanan engelli bireylerin erişimini kısıtlamaktadır. Ayrıca meydanda alanı bölen net sınırların çekilmiş olması kullanıcıları psikolojik olarak olumsuz etkilenmektedir.
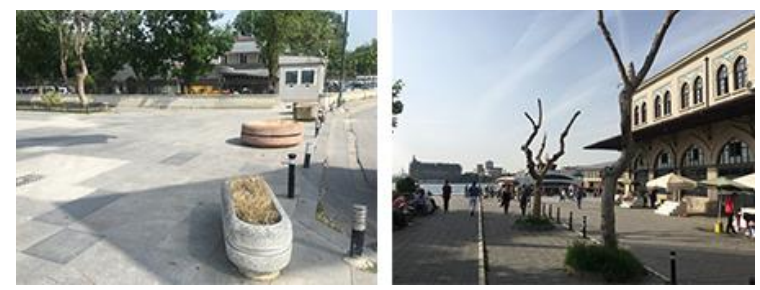

Şekil 13. Kentsel Donatı Elemanlarının Başka İşlevler İle ve Sınırlayıcı Elemanların Gelişigüzel Kullanımı (Kutsal Göllü, 2018)

Her iki sınırlayıcı kullanımında da meydana özel araçların girmesi engellenememiştir. Meydan ve çevresindeki alanlar çeşitli kamu kurumu, özel işletme ve kişilerce otopark olarak kullanılmaktadır (Şekil 14).
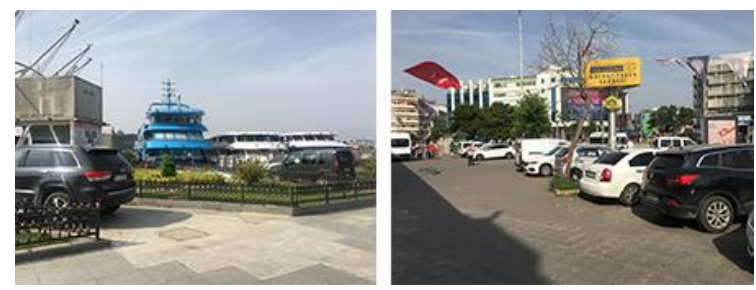

Şekil 14. Meydanın Otopark Olarak Kullanımı (Kutsal Göllü, 2018)

Meydanın tamamında yeșil alanlar ile yaya yolları arasına ergonomik ölçütler açısından alçak sinırlayıcı grubundan, malzeme, desen ve doku birliği olan elemanlar eklenmiştir (Șekil 15). Görsel konfor açısından aynı tasarımın sürdürülmesi olumlu olmakla birlikte tasarımda kullanılan desen ve renkler hem meydanın hem de yeşil alanların önüne geçmekte, sert ve baskın sınırlar oluşturmaktadır. Kullanıcı ile yeşil alanlar arasında keskin sınırların çekilmesi kamusal alanlarda yeşilin işlevinin de tartışıldığı başka gündemleri oluşturmaktadır. Ayrıca keskin sınırlar oluşturulması, yeșil alanların etrafında kalan sert zeminlerin yayalar tarafından geçiș yolu olarak kullanılmasına ve meydan bütünlüğünün kaybedilmesine neden olmaktadır.
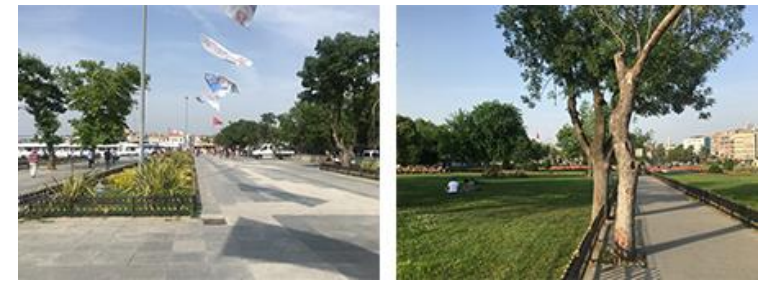

Şekil 15. Yeşil Alan Sınırlayıcıları (Kutsal Göllü, 2018)

Kadıköy Rıhtım Meydanı'nda yer alan oturma elemanları yayaların kullanım aksının üzerinde gelişigüzel bir biçimde konumlandırılmıştır. Arkalıklı ve arkalıksız iki farklı tipte kullanılan oturma elemanlarının tasarımı, kent içindeki diğer kamusal alanlarda da görülebilen standart oturma yüzeyi ahşap olan beton döküm ayaklı ve antropometrik açıdan yetişkin bireyin oturmasına elverişli $45 \mathrm{~cm}$ enindeki tasarımlardır (Şekil 16). Oysaki meydana ve Kadıköy'ün potansiyeline uygun, özgün, çağdaş ve estetik çözümlerle oturma birimlerinin planlanması kullanıcıların alanda geçireceği zamanı arttıracaktır. Oturma birimleri yerleşimlerinden bağımsız, tekil olarak düşünüldüğünde antropometrik ölçütleri karşılaması nedeniyle ergonomik ölçütlere uygun olmaktadır. Ancak kamusal alanın ergonomik tasarım ölçütleri düşünüldüğünde meydandaki konumları hatalı ve kullanıcı yoğunluğuna göre sayıları yetersizdir.
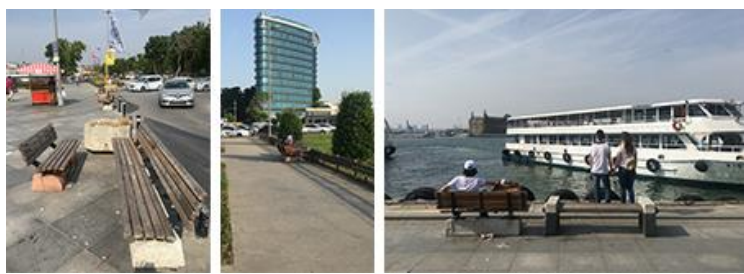

Şekil 16. Meydandaki Oturma Birimleri (Kutsal Göllü, 2018) 
Oturma birimlerinin sayısal yetersizliğinin en önemli sebebini, meydanda hissedilen üst örtü eksikliği, oturma öğelerinin konumlarının doğru seçilmemesi ve günün büyük çoğunluğunda güneş altında kalması oluşturmaktadır. Bu durum kullanıcıların gölge olan duvar, merdiven, bitki kasaları vb. düz yüzeylere oturmalarına neden olmaktadır (Şekil 17).
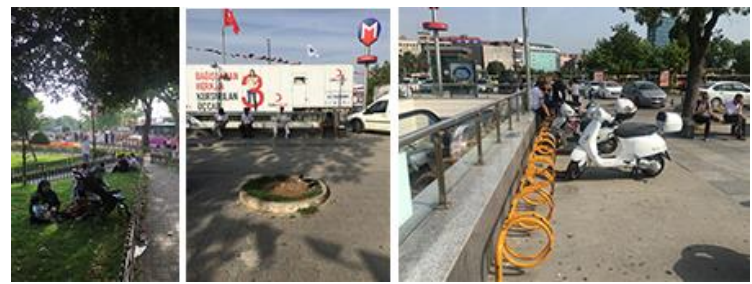

Şekil 17. Meydandaki Alternatif Oturma Şekilleri (Kutsal Göllü, 2018)

Yürütülen anket ve görüşme çalışmalarının oturma birimiyle ilgili sonuçları gözlemler ile paralellik göstermektedir. Kullanıcıların büyük bir çoğunluğu oturma birimleri hakkında olumsuz (\%60 kötü, \%30 ne iyi ne kötü) görüşler bildirmişlerdir.

Kamusal alanlarda çöp kutuları alanların temiz tutulabilmesi ve görsel konforun sağlanması açısından önemli donatı elemanlarıdır. Yoğun insan trafiğinin olduğu Kadıköy Rıhtım Meydanı'nda çöp kutularının kişi sayısından bağımsız, dolayısıyla yetersiz olduğu tespit edilmiştir. Donatının alan içindeki konumları "gelişigüzel" izlenimi uyandırmaktadır. Yayaların geçiş güzergahından, oturma birimlerinden ve yoğun kullanım alanlarından bağımsız konumlandırılmışlardır. Çöp kutularının bakımsız ve açık olmaları da sağlıksız ortamlar yaratarak görsel kirliliğe sebep olmaktadır (Şekil 18).
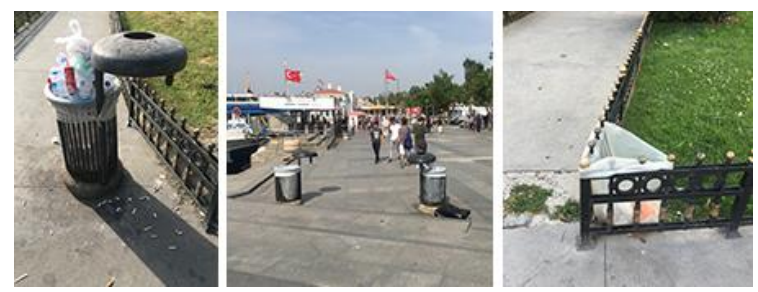

Şekil 18. Meydandaki Çöp Kutuları (Kutsal Göllü, 2018)

Yapılan anket çalışması sonucunda da çöp kutuları kullanıcılar tarafından \%63,3 oranında "kötü" ve \%33,3 oranında "ne iyi ne kötü" olarak nitelendirilmiştir. Mülakatlar sırasında ise çöp kutuları ile ilgili olarak kullanıcıların tamamı "yetersiz, sağlıksız, bakımsız, eski, aşırı dolu" gibi tanımlamalar yapmışlardır.

Meydan boyunca farklı form ve boyutlarda bitki kasaları bulunmaktadır. Donatıların seçiminde ergonomik ve estetik değerlerin dikkate alınmadığ belirlenmiştir. Bitkiler genellikle bakımsız olmakla birlikte, kasaların birçoğunda yeşil öğe bulunmaktadır. Ayrıca oturma birimi ile beraber tasarlanan bitki kasalarının oturma kısımlarının sökülerek kullanılması eski ve bakımsız bir görüntü oluşturmaktadır Kasaların tasarım amaçları dışında, alana araç girişinin önlenmesinde sınırlayıcı eleman gibi kullanıldığı da tespit edilmiştir (Şekil 19).
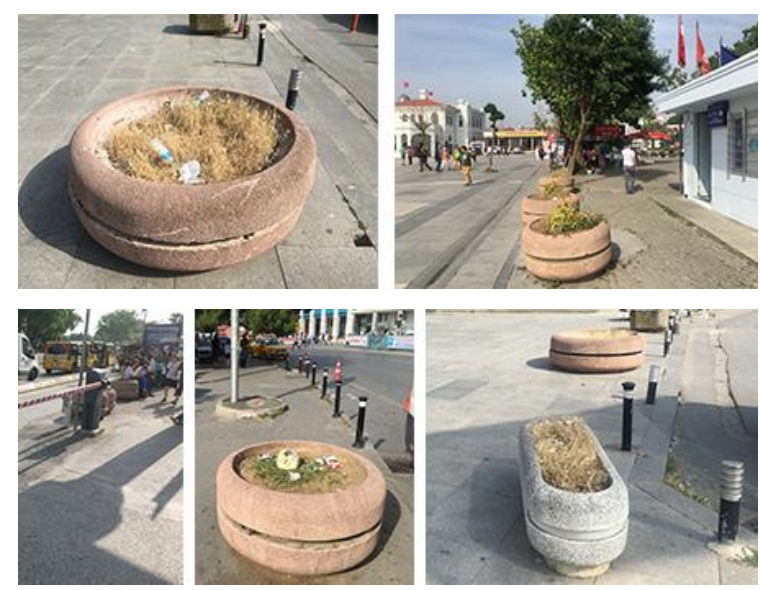

Şekil 19. Bitki Kasaları ve Kullanımları (Kutsal Göllü, 2018)

Kamusal alanlardaki telefon kabinleri cep telefonlarının yaygınlaşmasıyla birlikte kullanım değerini kaybetmişlerdir. Ancak meydan gibi toplanma alanlarının olduğu yerlerle acil durum ihtimaline karşı kent halkının iletişim kurmasını sağlamak amacıyla bulunması gereken donatı elemanlarındandır. Örneklem alanında bulunan telefon kabinlerinin birbirinden farklı tasarımlarda, uyumsuz, estetik olarak yetersiz ve bakımsız olduğu tespit edilmiştir. Kentsel donatı içerisinde ortak kullanım araçlarının her insan için erişilebilir olması gerekirken, telefon kulübeleri tekerlekli sandalye kullanan engellilerin ve çocukların kullanımına olanak sağlamamaktadır (Şekil 20). 


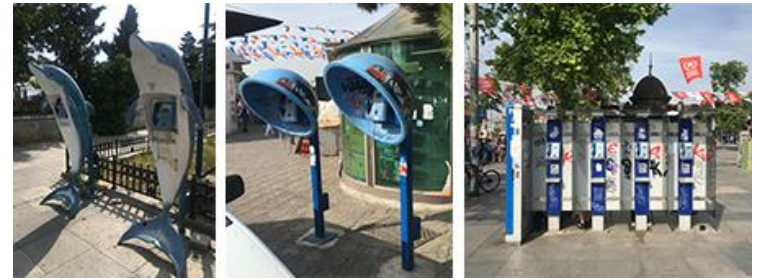

Şekil 20. Meydandaki Telefon Kulübeleri (Kutsal Göllü, 2018)

Otobüs durakları; insanların ulaşım amacıyla kullandıkları toplu taşıma araçlarından olan otobüsleri, araç trafiğinden ayrı, rahat bir şekilde beklemeleri amacı ile yapılan duraklama mekanlarıdır. Tasarım aşamasında yapım kolaylığı, estetik değerlere uygunluk, çevre ile uyum, amaca uygunluk, insanları güvence altına alması ve çevre koşullara karşı koruması dikkat edilmesi gereken hususlardır (Şişman ve Yetim, 2004). Alandaki otobüs duraklarında oturma birimlerinin bulunması engelli ve yaşlıların kullanımını kolaylaştırmaktadır. Üst örtüsünün opak veya yarı saydam olması sayesinde de güneşin etkileri engellenmekte ve gölge alanlar yaratılmaktadır. Bütün bu veriler otobüs duraklarında ergonomik ölçütler açısından istenilen kalitenin yaratıldığını göstermektedir (Şekil 21).
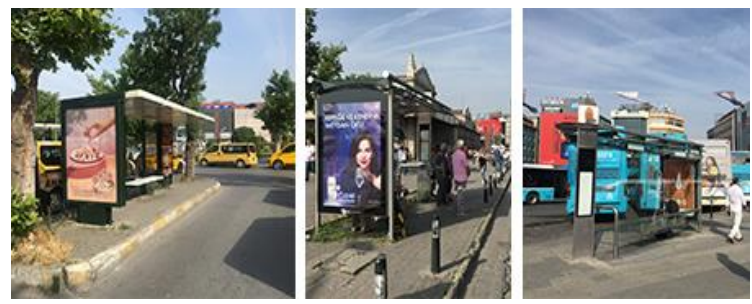

Şekil 21. Alandaki Otobüs Durakları (Kutsal Göllü, 2018)

Ancak otobüs duraklarının tasarım ve estetik değerleri meydan çevresi ile ilişki kuramamakta, İstanbul'un başka yerlerinde de görülen standart durak modeli olmakta ve sadece işlevsel olarak kullanıcı memnuniyetini sağlamaktadır.

Kadıköy Rıhtım Meydanı geniş alanı nedeniyle kentlinin dikkatini çekebilecek nirengi noktalarına ihtiyaç duymaktadır. Bu ihtiyacını kentsel donatılar içinde kültürün yansıması olan heykeller aracılığıyla yerine getirmektedir. Örneklem alanında iki adet heykel bulunmaktadır. Bunlardan ilki meydanın orta noktasına denk gelen "Atatürk Heykel"dir. Anıtın 2009 yılındaki altın rengi ile arka plandaki bitkilerin renk ve dokusu birbirine kontrast oluşturduğundan görsel konfor açısından doğru ve istenilen bir yaklașım olușturmuștur. Günümüzde heykelin rengi koyulaşmıştır. $\mathrm{Bu}$ durum kontrast etkisini azaltmakla birlikte, arkasındaki bitki yoğunluğunun korunuyor olması heykelin algılanması adına olumlu etkisini devam ettirmektedir (Şekil 22).
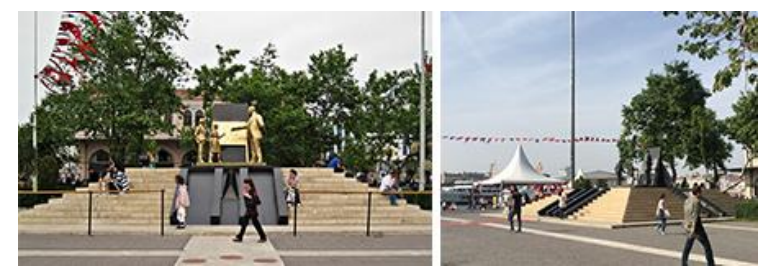

Şekil 22. Atatürk Heykeli 2009-2018

(Yılmaz, 2009; Kutsal Göllü, 2018)

Meydandaki ikinci heykel ise, "Kadıköy Balıkçısı" heykelidir. Günümüzde heykel çevresine kentsel düzenleme yapılmış, ancak düzenleme görsel konfor açısından heykelin algılanmasında olumsuz etki yaratmıştır. Heykel kaidesinin yer zeminiyle birlikte olması, yeşil bitkilendirme içinde kalması ve arkasında fon oluşturulmadan, dolmuş durakları ve araç trafiği görünümü bulundurması görüntü karmaşası yaratmaktadır. (Şekil 23). Heykeli ön plana çıkartacak ergonomik ölçütlerin kullanılarak yeni düzenlemelerin yapılması meydanın kullanımını ve estetik kalitesini arttıracaktır.

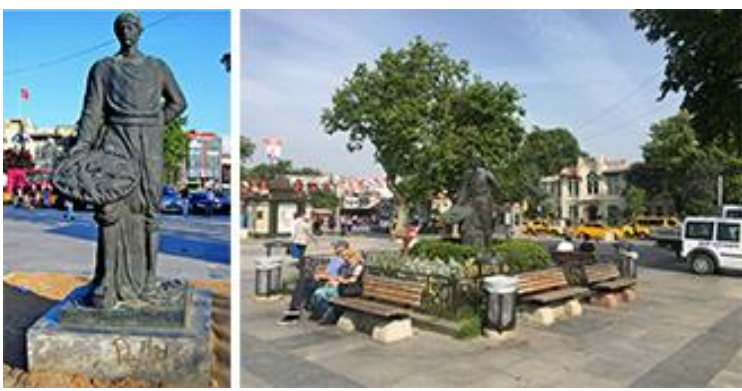

Şekil 23. Kadıköy Balıkçısı Heykeli ve Çevre Düzenlemesi 2009-2018

(Yılmaz, 2009; Kutsal Göllü, 2018)

Kadıköy Rıhtım Meydanı, günün her saati yoğun olarak kullanılan bir kentsel alandır. Toplu taşımanın yoğun olarak kullanıldığı sabah ve akşam saatlerinde kentlinin yiyecek ve içecek gibi temel ihtiyaçlarına ulaşması önem arz etmektedir. Bu nedenle alanda çok sayıda büfe, simit tezgahı vb. satış birimi tespit edilmiştir. Özellikle vapur iskeleleri etrafında yoğunlaşmış olan büfelerin çevrelerine görsel açıdan olumsuz etki yaptıkları gözlenmiştir. Büfe çevrelerinin "depo" olarak kullanılması ve 
tasarımlarında bütünlük bulunmaması meydanda kirli bir görüntü oluşturmaktadır. İçerisinde pişirme işleminin yapıldığı büfe alanlarında kötü kokular oluşmakta ve sağlıksız çevreler yaratmaktadır (Şekil 24).
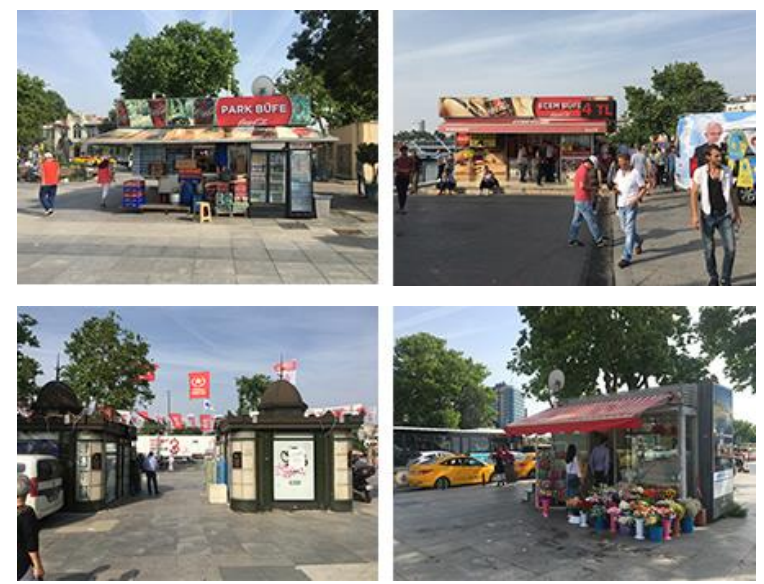

Şekil 24. Meydanda Bulunan Sabit Satış Birimleri (Kutsal Göllü, 2018)

Yiyecek ve içecek dışında meydanda çiçekçilerin Haldun Taner Sahnesi etrafında yoğunlaştığı tespit edilmiştir. Açık satış alanlarının çevresine yığılan çeşitli malzemeler, gelişigüzel yerleştirilen kutular ve satış stantları kaldırım kullanımını ve yaya trafiğini etkileyerek hem kullanıcı hem de satıcı açısından kullanıcı ergonomisini olumsuz yönde etkilemektedir. Haldun Taner Sahnesi ve yakın çevresinde estetik açıdan da olumsuz görüntüler ortaya çıkardığı belirlenmiștir (Şekil 25). Genel anlamda, işlevsel olarak önem taşıyan büfe ve satış birimlerinin estetik ve hijyen açısından çevresine olumsuz etkiler yaptığı gözlenmiştir.
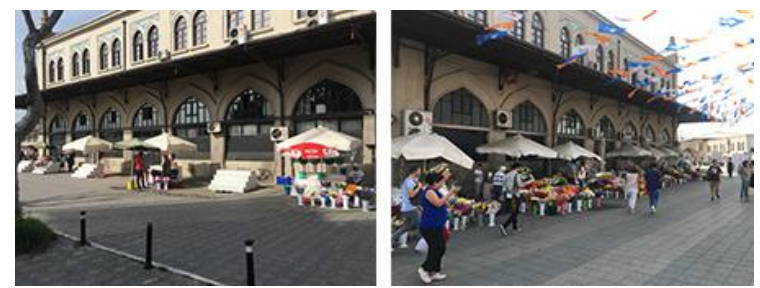

Şekil 25. Meydanda Bulunan Çiçekçiler (Kutsal Göllü, 2018)

Yürütülen anket çalışması sonucunda meydandaki büfe ve satıș birimlerine dair kullanıcı cevapları, \%33,3 oranında "iyi", \%30 oranında "ne iyi ne kötü", \%36,7 oranında ise "kötü" seçeneğiyle yakın sonuçlar vermiştir. Görüşmeler sırasında insanların büfelerle ilgili genel yaklaşımının erişebilirlik ve istenilen ürünlere ulaşma kolaylığı olduğu, ergonomik ve estetik olarak değerlendirmenin yapılmadığı gözlenmiştir.

Kadıköy Rıhtım Meydanı gibi insan yoğunluğu fazla olan ve farklı yönelimleri bulunan kamusal alanlarda, yön ve işaret levhaları alandaki öğeler hakkında bilgi veren önemli elemanlar haline gelmektedir. Yükseklik, boyut ve konumlarına özellikle dikkat edilmeli, insan boyuna yakın veya daha alçak yapılmamalı ve yayaların geçişine engel teşkil etmemelidir. Aynı zamanda verilmek istenen bilgi ve yönü açlk bir şekilde ifade etmeli, karışıklıkları ortadan kaldırmalıdır.

$\mathrm{Bu}$ anlamda yapılan incelemede, alanda yeterli düzeyde yönlendirme levhası bulunamamıştır. Alana yabancı olan kullanıcılarda özellikle ulaşımda problem yaşadıkları; toplu taşımadan inenlerin gitmek istedikleri yeri bulmada veya ulaşmak istedikleri toplu taşımanın yönünü bulamadıkları gözlenmiștir. Meydanda yalnızca Haldun Taner Sahnesinin ve Metro çıkışını belirten bilgi tabelasına rastlanmış ancak insan boyunda konumlandırılması, gidilecek yönü açı bir şekilde ifade etmemesi, dikkat çekici ve fark edilir olamaması nedeniyle hem mekansal hem de görsel konfor açısından olumsuz örnekleri oluşturduğu belirlenmiştir (Şekil 26). Gözlemlerle paralellik oluşturacak şekilde ankete katılanların \%56,7'si meydandaki yönlendirme tabelalarını "kötü" olarak nitelendirmiştir.
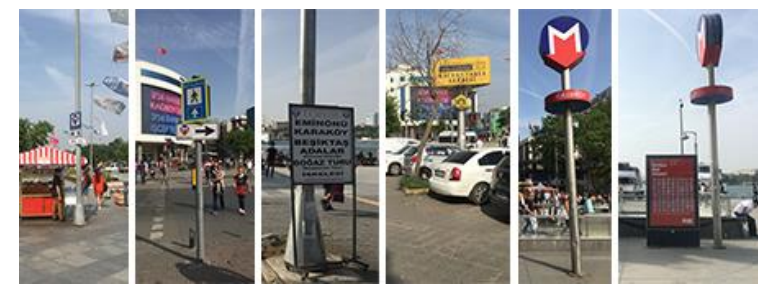

Şekil 26. Meydandaki Yön ve İşaret Elemanlar (Kutsal Göllü, 2018)

Döşeme elemanları, peyzaj çalışmalarının temel öğesi olup, üç boyutlu mekanın zeminini oluştururlar. Doku, renk, çizgi, form vb. özellikleri dikkate alınarak planlamalarda kullanılan bu elemanlar, işlevselliklerinin yanında estetik açıdan da alanı tamamlayıcı nitelikte olmalıdır (Başal vd., 1997; Der; Şişman ve Yetim, 2004). Kamusal alanlarda zeminin, yürüme sırasında kullanıcıları rahatsız etmeyecek, yağışlı havalarda kaygan yüzeyler oluşturmayacak ve engelliler için gerekli 
kabartılmış kaplama malzemelerini içerecek şekilde tasarlanmış olması ve doğru kaplama malzemelerinin seçilmiş olması gerekmektedir Çekmecelioğlu vd., 2017).

Kadıköy Rıhtım Meydanı'nda zemin kaplama malzemesi açısından olumlu hiçbir alan bulunamamıştır. Meydanın genelinde basamak oluşturmaya uygun olmayan kot farkllıkkları bulunmaktadır. Yıllar içinde sahilin birkaç kez doldurulması nedeniyle farklı kademelerde bordür taşları görülmektedir (Şekil 27). Eskiyen, kırılan, kopan zemin kaplama malzemelerinin arası betonla doldurularak yapılan döşeme iyileștirme çabaları ortaya olumsuz bir tablo çıkarmaktadır (Şekil 28). Alanın bütününde birbiri ile ilişki kurmayan farklı ölçü, renk ve dokudaki malzemeler yan yana gelmektedir (Şekil 29). Aynı zamanda sahilin doldurularak genişletilmesi sert zemin miktarını arttırmış ve doldurulan alan beton olarak bırakılmıştır.
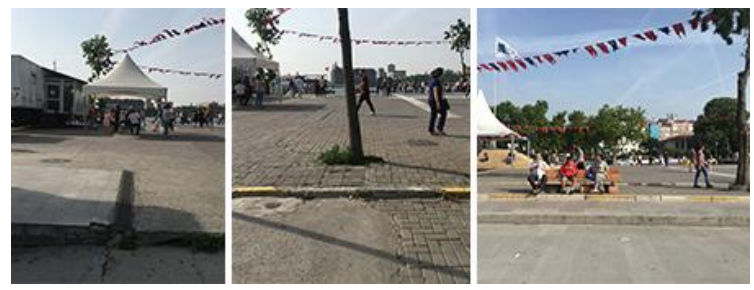

Şekil 27. Meydandaki İlișkilendirilemeyen Kot Farklılıkları (Kutsal Göllü, 2018)
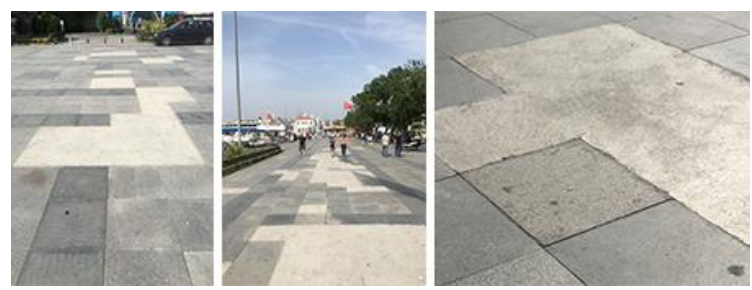

Şekil 28. Zemin Döșemesindeki Beton Dolgular (Kutsal Göllü, 2018)

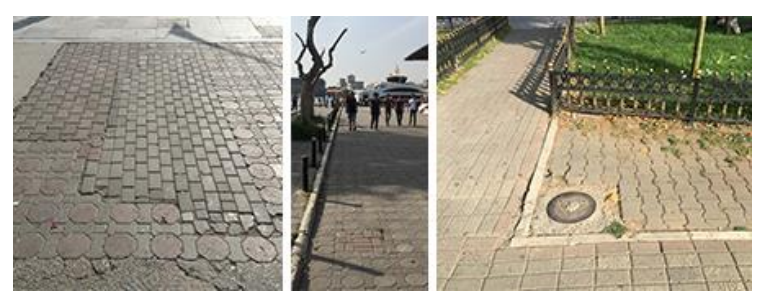

Şekil 29. Meydandaki Farklı Zemin Döşeme Malzemelerinin Kesişimi (Kutsal Göllü, 2018)
Zemin döşemesindeki olumsuzluklar bedensel engelli bireylerin meydan içindeki erişimlerini olumsuz yönde etkilemektedir. Ayrıca meydanın, bir noktası hariç geri kalan hiçbir noktasında, görme engelliler için hissedilir kılavuz yüzeyler bulunmamaktadır (Şekil 30).

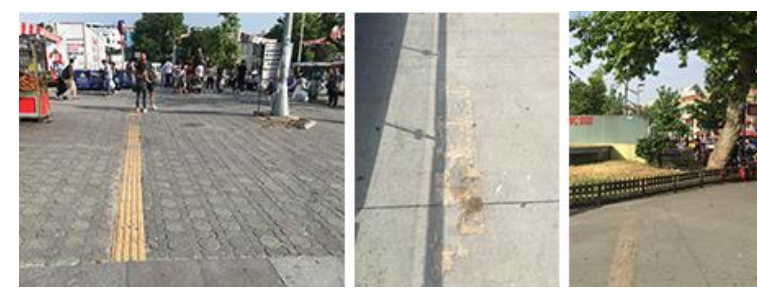

Şekil 30. Meydandaki Görme Engelliler İçin Kılavuz Yüzeyler (Kutsal Göllü, 2018)

Mevcutta nispeten zemin döşemesinin düzenli olduğu yerlerde zemine gelişigüzel yerleştirilen rögar kapakları, ızgaralar, çiçeklikler vb. uygulamalar, görsel olarak uyumsuz malzeme seçimi, bakım ve onarım yetersizliği nedeniyle niteliksiz zemin yüzeyleri yaratmıștır (Șekil 31).
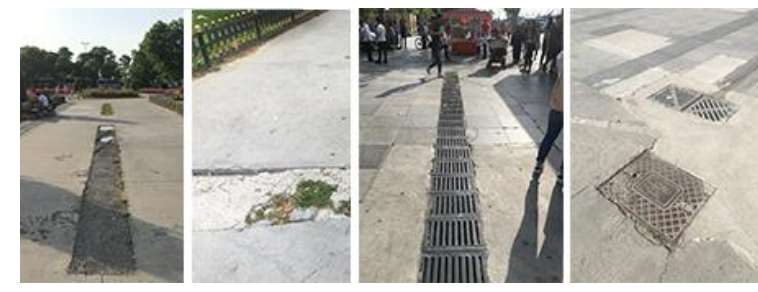

Şekil 31. Zemin Döșemesindeki Olumsuzluklar (Kutsal Göllü, 2018)
Yürütülen anket çalışması sonucunda, zemin yapısını kullanıcıların \%60'ı kötü ve \%33,3'ü ne iyi ne kötü olarak değerlendirmiştir. Ankete katılanların \%93,3 gibi yüksek bir oranı meydandaki zemin malzemesi hakkında olumsuz görüş belirtmiştir. Ankete katılanların tamamının (\%90 kötü, \%10 ne iyi ne kötü) meydanın engelli vatandaşın kullanımına kesinlikle uygun olmadığını belirtmiş olması Kadıköy Rıhtım Meydanı'nın kamusal işlevini sorgulatmaktadır.

Kamusal alanlarda engelsiz ulaşımında önemli donatılarından biri olan rampaların meydanda yeterli sayıda ve konumda olmadığı tespit edilmiştir. $\mathrm{Bu}$ tespitte zemin döşemesindeki planlama hatalarından kaynaklı kot farklılıklarının etkisi büyüktür. Meydanda rampalar bulunmasına rağmen alanın tamamı düşünüldüğünde tekerlekli sandalye 
ulaşımı birçok noktada kesintiye uğramaktadır. Alanda bulunan az sayıdaki rampa ise gerek eğimi ve boyutları gerekse de kullanım yeri ve erişim noktası açısından kabul edilebilir uygulamalar değildir (Şekil 32). Rampaların ergonomisi ile ilgili soruya ankete katılanlardan 32 kişi $(\% 53,3)$ "kötü", 22 kişi $(\% 36,7)$ "ne iyi ne kötü" seçeneğini işaretlerken, yalnızca 6 kişi (\%10) "iyi" olarak cevaplandırmıştır.
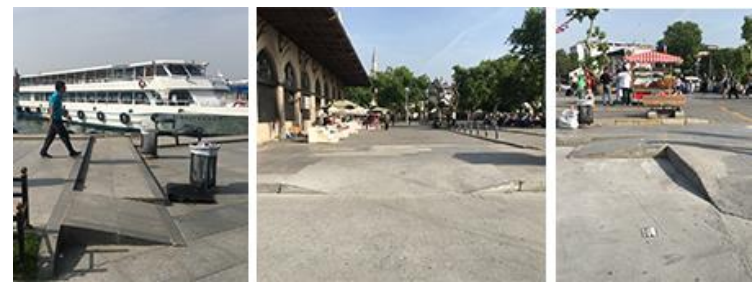

Şekil 32. Meydandaki Rampalar (Kutsal Göllü, 2018)

Kamusal alanların her vatandaşa eşit şartlarda erişim hakkı tanıması gerekir. Ancak Kadıköy Rıhtım Meydanı toplumumuzdaki engelli vatandaşları dışlayıcı planlama düzeni içindedir.

Merdivenler kamusal alanlardaki kot farkının düzenlenmesinde ve kullanıcı sürekliliğinin sağlanmasındaki peyzaj düzenleyicilerdendir. Kamusal alanı kullananların geniş yaş aralığı basamak yüksekliğine etki etmekte; basamak sayısı ve ölçülerinin ergonomik standartlara uygun olarak düşünülmesi kullanım kolaylığı sağlamaktadır. Kadıköy Rıhtım Meydanı'nda zemindeki kot farklılıkları düzenlenmediğinden merdiven olarak nitelendirilebilecek çıkışlar oldukça azdır. Metro giriş ve çıkışlarında merdivenler ergonomik koşulları yerine getirmektedir. Alan içerisindeki birkaç basamaklık çıkışlarda rıht yüksekliklerinin belli bir standardı bulunmamaktadır (Şekil 33).

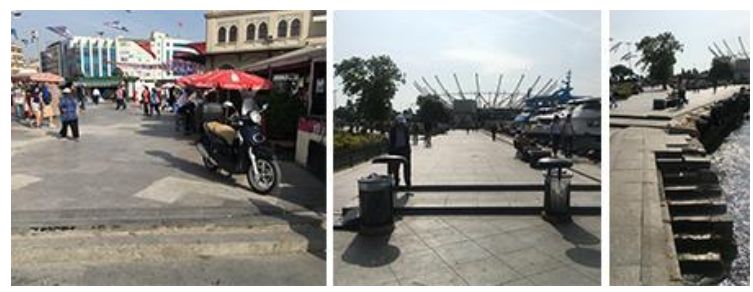

Şekil 33. Meydandaki Merdiven Düzenlemeleri (Kutsal Göllü, 2018)

Meydanda yapılan gözlem sırasında kentlinin alanı sıcak günlerde dinlenmek ve serinlemek amaciyla kullandığ alanlarda, yeşil alanların oluşturduğu gölgeliklerde sağlanmaktadır (Şekil 34). Meydanlarda yeșil alanlar hem görsel konfor hem de termal konforun oluşturulması açısından önemli alanlardır.
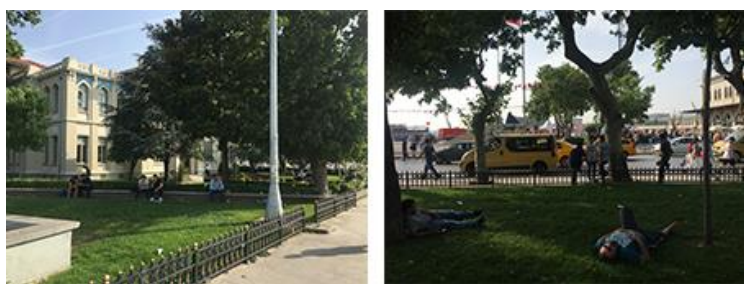

Şekil 34. Yeşil Donatının Gölgelik Kullanımı (Kutsal Göllü, 2018)

Meydan geniş yeşil alanlara sahiptir. Meydanı bölen yolun kuzeydoğusunda kalan alanda geniş gölgeli ağaçlar, güneydoğusunda kalan alanda ise mevsim çiçekleri ve yola sıralı ağaçlar yer almaktadır. Ancak hatalı kentsel planlama sonucu yeşil alanların deniz ile ilişkisi zayıf kalmıştır. Denize paralel yol güzergahında birçok ağacın kuruduğu ve bakımsızlık nedeniyle kesildiği; yerlerine yenilerinin dikilmediği tespit edilmiştir. Bu durum yeşil alanların kısmi donatı olarak "serpiştirilmesi"ne neden olmuştur (Şekil 35).
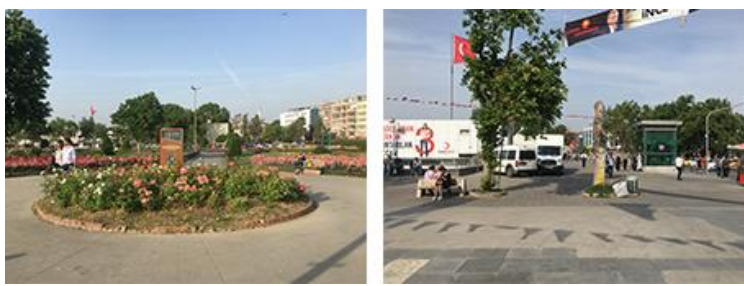

Şekil 35. Farklı Yeşil Donatı Alanları (Kutsal Göllü, 2018)

Yürütülen anket çalışmasında kullanıcıların \%53,3'ü peyzaj alanlarını "kötü" olarak nitelendirmiştir. Karşılıklı görüşmeler sonucunda daha çok gölge veren ağaç olmamasından ve deniz tarafındaki ağaçların az olması nedeniyle sıcak günlerde meydandaki gölge alanların azlığından şikayet edilmiştir.

\subsection{Kadıköy Rıhtım Meydanı'nda Düzenlenen Anket Çalışmasının İrdelenmesi}

Kamusal alanların ergonomik ölçütleri değerlendirilirken kentsel donatıların antropometrik ölçülere uygunluğunun yanında konfor verilerinin de değerlendirilmesi 
gerekmektedir. Bu nedenle çalışmada, kamusal alanı deneyimleyen kullanıcıların memnuniyeti esas ölçüt olarak alınmıștır.

Farklı gün ve saatlerde meydanda bulunan 60 kullanıcıya, meydana ve meydanı oluşturan kentsel donatılara dair toplam 16 değerlendirme sorusu yöneltilmiştir. Cevaplar "iyi", "ne iyi ne kötü" ve "kötü" olmak üzere üçlü sistem üzerinden analiz edilmiştir (Tablo 1).

Tablo 1. Kadıköy Rıhtım Meydanı Anket Çalışması Sonuçları

\begin{tabular}{|c|c|c|c|c|c|}
\hline \multirow{3}{*}{ No } & \multirow{3}{*}{ Sorular } & \multirow{3}{*}{ Değ. } & \multicolumn{3}{|c|}{ Memnuniyet Derecesi Skalası } \\
\hline & & & Iyi & $\begin{array}{l}\text { Ne lyi/Ne } \\
\text { Kötü }\end{array}$ & Kötü \\
\hline & & & 1 & 0 & -1 \\
\hline \multirow{2}{*}{1} & \multirow{2}{*}{$\begin{array}{l}\text { Meydana ulaşım rahatlığınızı } \\
\text { değerlendirir misiniz? }\end{array}$} & Kişi & 20 & 30 & 10 \\
\hline & & $\%$ & 33,3 & 50,0 & 16,7 \\
\hline \multirow{2}{*}{2} & \multirow{2}{*}{$\begin{array}{l}\text { Meydan güvenliği hakkında ne } \\
\text { düşünüyorsunuz? }\end{array}$} & Kişi & 18 & 30 & 12 \\
\hline & & $\%$ & 30,0 & 50,0 & 20,0 \\
\hline \multirow{2}{*}{3} & \multirow{2}{*}{$\begin{array}{l}\text { Meydanın zemin döşemesi hakkında ne } \\
\text { düşünüyorsunuz? }\end{array}$} & Kişi & 4 & 20 & 36 \\
\hline & & $\%$ & 6,7 & 33,3 & 60,0 \\
\hline \multirow{2}{*}{4} & \multirow{2}{*}{$\begin{array}{l}\text { Meydan ve çevresindeki merdivenlerin } \\
\text { konumu ve kullanım rahatığını } \\
\text { değerlendirir misiniz? }\end{array}$} & Kişi & 6 & 20 & 34 \\
\hline & & $\%$ & 10,0 & 33,3 & 56,7 \\
\hline \multirow{2}{*}{5} & \multirow{2}{*}{$\begin{array}{l}\text { Meydan ve çevresindeki rampaların } \\
\text { konumu ve kullanım rahatlı̆ı̆ıı } \\
\text { değerlendirir misiniz? }\end{array}$} & Kişi & 6 & 22 & 32 \\
\hline & & $\%$ & 10,0 & 36,7 & 53,3 \\
\hline \multirow{2}{*}{6} & \multirow{2}{*}{$\begin{array}{l}\text { Meydanın engelli (görme, duyma ve } \\
\text { tekerlekli sandalye kullanan vb.) } \\
\text { insanların kullanımına uygunluğunu } \\
\text { değerlendirir misiniz? }\end{array}$} & Kişi & & 6 & 54 \\
\hline & & $\%$ & 0,0 & 10,0 & 90,0 \\
\hline \multirow{2}{*}{7} & \multirow{2}{*}{$\begin{array}{l}\text { Meydandaki peyzaj öğeleri (ağaçlar, } \\
\text { çiçekler vb.) hakkında ne } \\
\text { düşünüyorsunuz? }\end{array}$} & Kişi & 10 & 18 & 32 \\
\hline & & $\%$ & 16,7 & 30,0 & 53,3 \\
\hline \multirow{2}{*}{8} & \multirow{2}{*}{$\begin{array}{l}\text { Meydandaki aydınlatma elemanları } \\
\text { hakkında ne düșünüyorsunuz? }\end{array}$} & Kişi & 12 & 34 & 14 \\
\hline & & $\%$ & 20,0 & 56,7 & 23,3 \\
\hline \multirow{2}{*}{9} & \multirow{2}{*}{$\begin{array}{l}\text { Meydandaki oturma bankları hakkında } \\
\text { ne düşünüyorsunuz? }\end{array}$} & Kişi & 6 & 18 & 36 \\
\hline & & $\%$ & 10,0 & 30,0 & 60,0 \\
\hline \multirow{2}{*}{10} & \multirow{2}{*}{$\begin{array}{l}\text { Meydandaki çöp kutuları için ne } \\
\text { düşünüyorsunuz? }\end{array}$} & Kişi & 2 & 20 & 38 \\
\hline & & $\%$ & 3,3 & 33,3 & 63,3 \\
\hline \multirow{2}{*}{11} & \multirow{2}{*}{$\begin{array}{l}\text { Meydandaki büfeler için ne } \\
\text { düşünüyorsunuz? }\end{array}$} & Kişi & 20 & 18 & 22 \\
\hline & & $\%$ & 33,3 & 30,0 & 36,7 \\
\hline \multirow{2}{*}{12} & \multirow{2}{*}{$\begin{array}{l}\text { Meydandaki kentsel donatıların (oturma } \\
\text { bankları, çöp kutuları, çiçek kasaları vb.) } \\
\text { yerleşimlerini değerlendirir misiniz? }\end{array}$} & Kişi & 2 & 20 & 38 \\
\hline & & $\%$ & 3,3 & 33,3 & 63,3 \\
\hline \multirow{2}{*}{13} & Meydandaki yönlendirme tabelaları & Kişi & 16 & 10 & 34 \\
\hline & hakkında ne düşünüyorsunuz? & $\%$ & 26,7 & 16,7 & 56,7 \\
\hline 14 & Meydandaki gölgeleme elemanları & Kişi & 2 & 6 & 52 \\
\hline 14 & hakkında ne düşünüyorsunuz? & $\%$ & 3,3 & 10,0 & 86,7 \\
\hline 15 & Meydandaki gürültü düzeyini & Kişi & 2 & 22 & 36 \\
\hline & değerlendirir misiniz? & $\%$ & 3,3 & 36,7 & 60,0 \\
\hline 16 & Meydanın hava kalitesini değerlendirir & Kişi & 10 & 30 & 20 \\
\hline & misiniz? & $\%$ & 16,7 & 50,0 & 33,3 \\
\hline
\end{tabular}

Anket, 30 kadın ve 30 erkek katılımcı üzerinde uygulanmıştır. Ankete katılanların \%53,3 oranı 3044 yaş aralığındadır. Katılımcıların dağılımları sırasıyla \%26,7 20-29 yaş; \%13,3 55 ve üzeri; \%3,3 45-54 ve \%3,3 20 yaşın altındadır. Katılımcıların eğitim durum, \%50 lisans mezunu, \%36,7 lisansüstü mezunu, \%10 lise mezunu ve \%3,3 ortaokul mezunudur. İlkokul mezunu olan ve okur-yazar olmayan katılımcı bulunmamaktadır. Anketteki tek açık uçlu soru olan "meydanın kullanım amacının belirlenmesi"ne yönelik soruya katılımclar benzer cevaplar vermiştir. Bunlar sırasıyla, "ulaşım, bekleme ve buluşma, gezme, dinlenme ve vakit geçirme" olarak belirlenmiştir.

Kullanıcıların 16 soruda meydanı değerlendirmeleri sonucunda, sorular içinde alana dair hiçbir "olumlu" sonuç çıkmamıştır. Cevaplar genel olarak "kötü" ve "ne iyi ne kötü" üzerinde yoğunlaşmaktadır. Kadıköy Rıhtım Meydanını değerlendirenler, alana ulaşımı ve alanın güvenliğini $\% 50$ oranında "ne iyi ne kötü" olarak nitelendirmişlerdir. Her iki soru içinde ikinci yüksek değer "iyi" yönünde verilmiștir. Bu değerlendirmeler meydan için olumlu sayılabilecek sonuçları oluşturmaktadır.

Meydandaki aydınlatma elemanlarının ve aydınlatma elemanlarıyla ilişkili olarak meydan güvenliğinin sonuçları "ne iyi ne kötü" olarak değerlendirilmiştir. Meydanın zemin döşemesi, merdiven ve rampaları; zemin verilerine bağlı olarak engelli erişimi; peyzaj öğeleri, oturma bankları, çöp kutuları, büfeler, yönlendirme tabelaları ve gölgelik elemanları erişebilirlik, ergonomik ölçütler ve estetik değerler bütününde ele alınarak olumsuz olarak değerlendirilmiştir. Kentsel donatıların olumsuz sonuçları meydandaki kentsel donatıların yerleşimlerinin değerlendirilmesine yönelik soruya verilen \%63,3 "kötü" ve \%33,3 "ne iyi ne kötü" yanıtıyla da pekiştirilmektedir.

İşitsel ve termal konforun belirlenmesi için özel olarak sorulan gürültü düzeyi ve hava kalitesinin değerlendirilmesine ait sonuçlar ise sırasıyla \%60 "kötü"; \%50 "ne iyi ne kötü" olarak belirtilmiştir. Katılımcl görüşmelerinde, meydana dair "kirli, karışık ve kaotik" sıfatları sık sık tekrarlanmıştır.

\section{Tartıșma}

İnsanlar doğaları gereği öznel yaşam alanlarını fiziksel ve psikolojik ihtiyaçları doğrultusunda değiştirme/dönüştürme eğilimi taşırlar. İster ofis masası olsun ister otel odası ya da yaşanılan ev birey aidiyet hissedebilmek için çevresini kişiselleştirir. Fakat kent kullanıcılarının kesişim alanı olan kamusal alanlar herkese aittir. Bireysel olarak değiştirmek ve kişiselleștirmek mümkün olmamaktadır. Kamusal alanlarda kentlinin aidiyet hissedebilmesi; tüm bireylerin fiziksel ve psikolojik ihtiyaçlarının belirlenip tasarım ölçütlerine yansıtılmasıyla gerçekleşebilir. Bu nedenle kamusal 
alanların tasarımında "ergonomik ölçütler" büyük önem taşır. Ergonomik ölçütleri yalnızca antropometrik veriler olarak görmemek gerekir. Özellikle bireylerin rahatını ve huzurunu sağlamada ergonominin konfor ölçütleri göz önünde bulundurulmalıdır.

Kamusal alanlar içinde meydanlar kent kimliğinin oluşturulduğu yerlerdir. Doğal çevre, toplumsal, sosyo-kültürel yapı ve yapılı çevrenin karșılıklı etkileșimi sonucu yaratılan kent kimliği, kentsel donatılar aracllığıyla meydanlarda tasarım öğesi haline gelir. Kentsel donatıların işlevsel kullanımlarının yanında estetik değerlere de cevap verebiliyor olması meydanlara süreklilik ve bütünlük kazandırır. Böylece meydanlar, farklı kullanıcı gruplarının karşllıklı etkileşime geçtiği, sosyo kültürel paylaşımlarda bulunduğu ve iletişim kurduğu mekanlar haline gelir.

Kadıköy Rıhtım Meydanı, Anadolu yakasındaki coğrafi konumu ve kullanım değeri ile farklı kullanıcı gruplarının kesiştiği kamusal alanlardan bir tanesidir. Çalışma kapsamında yürütülen alan incelemesi, anket çalışması ve kullanıcı görüşmeleri sonucunda meydanda birçok problemin olduğu ortaya konmuştur. Meydanın kentsel ergonomik ölçütler açısından yeterince planlanmadığı, karmaşık ve yetersiz kaldığı belirlenmiştir. Kamusal mekan organizasyonuna yön veren erişebilirlik, ergonomik ölçütler ve estetik değerlerin karşıllığını meydanda bulmak mümkün değildir. Kamusal alanların her kullanıcıya açık olma durumu, Kadıköy Meydanı'nda engelli bireyleri kapsamamaktadır.

Kentsel donatıların meydandaki konumlarında görsel etkileşim dikkate alınmadığı gibi kamusal ihtiyacı da tam olarak karşılamamaktadır. Kentsel donatılar tekil olarak antropometrik ölçülere uygun objeler olarak tasarlanmışlardır. Fakat birbirleriyle olan ilişkilerinde ortak bir dil oluşturmadıklarından süreklilik yaratamamıştır. Donatıların herhangi bir alanda kullanılandan farklı olmaması kullanıcılar üzerinde meydan referansını oluşturmadaki en büyük eksikliktir. Bu nedenle Kadıköy Rıhtım Meydanı kamusal alan içinde meydan niteliği ile ön plana çıkamamakta, kentli için ulaşım aksı, geçiş rotası ve buluşma noktası olarak kalmaktadır.

Çalışmanın sonucunda Kadıköy Rıhtım Meydanı'nın sahip olduğu potansiyelin çok altında bir kullanım profili çizdiği görülmüştür. Bu nedenle meydanda yapılacak noktasal düzenleme ve geliştirmelerden ziyade bütüncül tasarım anlayışı ile alanın yeniden tasarlanması gerekmektedir. Meydanın denizle olan etkileşimi ve kullanıcı profilinin kültürel çeşitliliği göz önünde bulundurularak geliştirilecek, tüm kentin kullanımına ait, kullanabilirliliğin ve erişebilirliliğin ön planda olduğu planlama ve tasarım kararları sayesinde kentliler için yaşayan alanlar yaratılacaktır. Meydanın boyutları ve çok işlevli yapısı dikkate alındığında kullanıcıların görüşleri ve istekleriyle oluşturulan programın ulusal ve uluslararası platformlarda tartışmaya açılarak çok sayıda aktörün katılımıyla gerçekleșecek yarışma ortamının oluşturulması gerekir. Bu sayede İstanbul gibi yoğun kent yaşamı içerisinde, kentlinin "nefes alabileceği" modern ve kullanışlı kamusal alanlar herkesin katılımıyla yaratılmış olacaktır.

\section{Çıkar Çatışması}

Yazarlar tarafından herhangi bir çıkar çatışması beyan edilmemiştir.

\section{Kaynaklar}

Atılgan, A. (2017). Kadıköy Şehremaneti Binası. Erişim adresi : http://www.mimdap.org/?p=198663. Erişim tarihi: 16 Mayıs 2018.

Bayhan, B. (2011). Kadıköy Meydanı Yayalaștırılıyor. Erişim adresi

http://www.arkitera.com/haber/4442/kadikoy -meydani-yayalastiriliyor. Erişim tarihi: 16 Mayıs 2018.

Bayhan, B. (2016). İBB Kadıköy Rıhtımını Düzenliyor. Erişim adresi : http://www.arkitera.com/haber/27932/ibbninkadikoy-meydani-projesinin-insaati-basladi. Erişim tarihi: 16 Mayıs 2018.

Bayramoğlu, E. ve Özdemir, B. (2012). Trabzon Kent Merkezi, Uzun Sokak Kentsel Donatı Elemanlarının Kent Kimliği Açısından Değerlendirilmesi, Kastamonu Üniversitesi Orman Fakültesi Dergisi, 12(2), 182-191.

Baytin, N. (1988). Mimarlık - Ergonomi Antropometri ílişsisi. 1. Ulusal Ergonomi Kongresi, İTÜ Milli Prodüktivite Merkezi, Ankara.

Çekmecelioğlu, E., Bayram, Ö.F. ve Canbay Türkyılmaz, Ç. (2017). Kamusal Mekanların Ergonomik Ölçütler Açısından Değerlendirmesi: Eminönü Meydanı Örneği. 23. Ulusal Ergonomi Kongresi, Çukurova Üniversitesi, Adana, 26-28 Ekim 2017.

Çelikyay, S. ve Karayılmazlar, A.S. (2016). Bartın Kent Merkezlerindeki Kamusal Alanların Kentsel Ergonomi ve Kent Kimliği Açısından İncelenmesi, Bartın Orman Fakültesi Dergisi, 18(2), 224-238. 
Doğan, C. ve Altan, O. (2007). Kamusal Alanda Oturma Eylemi ve Ergonomik İlkeler, Megaron Dergisi, 2(3), 159-166.

Gürsel, D. (2012). Kadıköy'de Radikal Değişiklik. Erişim adresi : http://www.arkitera.com/haber/9636/kadikoy de-radikal-degisiklik. Erişim tarihi: 16 Mayıs 2018.

Habermas, J. (1995). Kamusal Alan: Ansiklopedik Bir Makale. Erişim adresi : http://www.birikimdergisi.com/birikimyazi/4966/kamusal-alan-ansiklopedik-birmakale\#.WvyZP4iFPIU. Erișim tarihi: 16 Mayıs 2018.

İnceoğlu, M. (2007). Kentsel Açık Mekanların Kalite Açısından Değerlendirilmesine Yönelik Bir Yaklaşım: İstanbul Meydanlarının İncelenmesi. Basılmamış Doktora Tezi, Yıldız Teknik Üniversitesi, İstanbul.

Karakoç, N. (2017). Kadıköy Rıhtıma Cami Onayı. Erișim adresi http://www.arkitera.com/haber/29567/kadiko y-rihtima-cami-onaylandi. Erişim tarihi: 16 Mayıs 2018.

Kuşkun, P. ve Yılmaz, H. (2003). Erzurum Kenti Bütününde Donatı Elemanlarının Kullanımı Üzerine Bir Araştırma, Atatürk Üniversitesi Ziraat Fakültesi Dergisi, 34(4), 345-351.

Öztürk Kurtaslan, B. (2005). Açık Alanlarda HeykelÇevre İlişkisi ve Tasarımı, Erciyes Üniversitesi Sosyal Bilimler Enstitüsü Dergisi, 18(1), 193-222.

\footnotetext{
$\checkmark$ Araştırma makalesinde kullanılan fotoğraflar birinci yazar Simge KUTSAL GÖLLÜ tarafindan 15-16-17 Haziran 2018 tarihlerinde Kadıköy Rıhtım Meydanı'nda çekilmiştir.
}

Rapoport, A. (1977). Human Aspects of Urban Form: Towards a Man-Environment Approach to Urban Form and Design. 1st Edition, Pergamon Press, New York.

Şahin, F. (2005). Alışveriş Merkezlerinin Biçimlenmesinde Önemli Boyutlardan Kamusal Mekan ve Kamusallık Olgusu. Yüksek Lisans Tezi, Karadeniz Teknik Üniversitesi, Trabzon.

Şerefhanoğlu, M. (1991). Kentsel Tasarımda Aydınlatmanın Rolü. 1. Kentsel Tasarım ve Uygulamalar Sempozyumu, Mimar Sinan Üniversitesi, İstanbul, 23-24 Mayıs 1991.

Şişman, E.E. ve Yetim, L. (2004). Tekirdağ Kentinde Donatı Elemanlarının Peyzaj Mimarlığı Açısından İrdelenmesi, Trakya Üniversitesi Fen Bilimleri Dergisi, 5(1), 43-51.

Ününgür, M. (1988). Gelişmekte Olan Ülkelerdeki Önemi Açısından Ergonomi-Mimarlık İlişkileri. 1.Ulusal Ergonomi Kongresi, İTÜ Milli Prodüktivite Merkezi, Ankara.

Yılmaz, Y. (2009). İstanbul'un Anıtları ve Heykelleri. Erişim adresi http://wowturkey.com/forum/viewtopic.php?t =9879\&start=60. Erişim tarihi: 18 Haziran 2018 .

Yılmaz Gürkan, E.T. (2015). Bakanlık'ın Kadıköy İnad. Erişim adresi : http://www.arkitera.com/haber/24364/bakanli kin-kadikoy-inadi. Erişim tarihi: 16 Mayıs 2018.

Yücel, G.F. (2006). Kamusal Açık Mekanlarda Donatı Elemanlarının Kullanımı, Ege Mimarlık Dergisi, 4(59), 26-29. 